\title{
Rights and Deaths: Government Reactions to the Pandemic*
}

José Antonio Cheibub ${ }^{\dagger}$

Ji Yeon Jean Hong $\ddagger$

Adam Przeworski ${ }^{\S}$

July 7,2020

\begin{abstract}
Democracies reacted slower than autocracies to the specter of the pandemic, and the most solidly democratic among them were particularly slow to react. We examine at which stages of the spread of the Covid governments introduced four measures that to varying degree abrogate liberal rights: school closings, bans on public meetings, compulsory lockdowns, and shutting work. We conclude that where rights are entrenched, encroaching on them is difficult. Yet we are struck that when the threat of death became sufficiently severe, many democracies resorted to the same measures as autocracies. Still, the reactions of democracies were highly heterogenous and we are unable to account for this heterogeneity.
\end{abstract}

\footnotetext{
*We are placing the paper in public domain now because the period under study is almost perfectly self-contained, so that results do not depend on the, yet uncertain, future dynamics of the pandemic. Moreover, there is nothing in this paper that depends on the knowledge of epidemiology or biology. For comments we are grateful to John Ferejohn, Roberto Gargarella, Tom Ginsburg, Florian Hollenbach, Steve Holmes, Ali Kagalwala, Alejandro Medina, Andrea Pozas Loyo, Julio Saguir, Maria Paula Saffon, and Ignacio Sanchez-Cuenca

${ }^{\dagger}$ Mary Thomas Marshall Professor, Texas A\&M University (cheibub@tamu.edu).

$\ddagger$ Assistant Professor, Hong Kong University of Science and Technology (jyhong@ust.hk).

$\S$ Carroll and Milton Petrie Professor Emeritus, New York University (adam.przeworski@nyu.edu)
} 


\section{Introduction}

Intending to reduce the rate of expansion of the Covid pandemic, governments around the world introduced a series of measures designed to limit "social distancing." They faced conflicting considerations. Measures that prevent deaths are economically costly $^{1}$ and all countries face a trade-off between protecting lives and protecting livelihoods. In the words of a seller of lottery tickets in the tourist center of Mexico City, "Either we die from the coronavirus or we die from hunger; we will have to choose" (El Pais, March 27). But, as distinct from autocracies, democracies must consider an additional trade-off: between health and basic liberal and democratic rights. As the President of Argentina, Alberto Fernandez, declared on June 26, "You cannot imagine how much I value liberty. But to be free one has to be alive." The decisions made by particular democratic governments may be and in fact were different, but political regimes with entrenched rights must be hesitant to adopt measures that limit them. Governments and publics in liberal democracies may be willing to accept more deaths in order to preserve these rights.

We examine the hypothesis that democratic governments were slower than autocratic ones in responding to the pandemic because they were concerned about preserving rights to associate, including to hold religious observances, to move freely, and to engage in economic activities. ${ }^{2}$ Given that we cannot directly observe the respect for rights in particular societies, this is a residual explanation. We reason that if the reaction of democracies remains slower even when the antecedent economic and sanitary conditions of particular countries are controlled for, the most plausible explanation is the respect for rights. Yet we are aware that not all rival explanations have been eliminated. Indeed, some of the patterns we discovered remain mysterious.

The motivation, the basic findings, and their interpretation are summarized in the section that follows, which is intended to be self-contained. For readers who want to delve into details, in the subsequent section we present statistical results concerning the two most important measures, compulsory confinement to residence and shutting down all non-essential work. Finally, in appendices we fill more descriptive details, show results of alternative statistical procedures, and provide a codebook of the variables used in the analyses.

\footnotetext{
${ }^{1}$ Spence and Long (2020) estimate that reducing mobility by $1 \%$ shrinks the GDP by $0.31 \%$. Eichenbaum, Rebelo, and Trabandt (2020) study the trade-off between deaths and incomes. Coibion, Gorodnichenko, and Weber (2020) examine the effects of lockdown on consumer spending and expectations in the U.S. Alvarez, Argente, and Lippi (2020), as well as Jones, Philippon, and Venkateswaran (2020), study optimal lockdown policies considering their economic costs.

${ }^{2}$ Two papers that attempt to explain why governments adopted particular measures are Cepaluni, Dorsch, and Branyiczki (2020), who find that democracies experienced more deaths than autocracies, and Frey, Chen, and Presidente (2020), according to whom autocracies adopted more stringent measures but with less effect on social distancing. In turn, two papers on the U.S. found that states with higher support for Republicans were less likely to adopt stringent measures: Adolph et al. (2020) and Barrios and Hochberg (2020).
} 


\section{Overview}

Citizens of democracies have rights. They include freedom of movement, the right to associate, to join in religious observances, to engage in legal economic activities, and to protect our privacy from the eyes of the State. Our democratic rights include the freedom to choose governments through elections and to control their actions through our elected representatives and the judicial institutions. These rights are enshrined in constitutions and protected by laws.

Thus, when China took aggressive measures against the spread of the Covid, they were decried in democratic countries as authoritarian, brutal, invasive, and repressive. They were all that: forced isolation of infected people and their contacts, restrictions on all movements, spying on cell phones, suppression of unwanted information. It was unthinkable that such measures could be utilized under democracy. The Director of Human Rights Watch, Kenneth Roth, criticized the launch of quarantine in Chinese cities and described the measure as a "radical" approach. The website Axis reported that "Many in the West watched in both horror and awe as Chinese authorities took historic measures to prevent the spread of the virus...." AlJazeera published an editorial entitled "China's approach to containing coronavirus cannot be replicated. China has gotten a grip on its coronavirus outbreak by deploying authoritarian methods of containment." The Business Insider commented that "China took at least 12 strict measures to control the coronavirus. They could work for the US, but would likely be impossible to implement." The New York Times thought that "The diversity of American democracy - the local governments, varied health services, strong news media and multiple religious institutions - preclude a China-like rule by authoritarian diktat." Deutsche Welle referred to "emergency measures that were otherwise known from authoritarian systems: curfews, assembly bans and cuts in religious freedom...." We were told that "Because the Chinese system operates in a totalitarian fashion, it could extend the quarantine to many people.... No democratic state is able to implement similar measures" (a French intellectual, Guy Sorman interviewed in Kultura Liberalna 586, Warsaw, March 31). Le Monde reported that, as of March 6, "There is no question to adopt measures of strict confinement which China - this non-democratic regime imposes on its population. In France, it would be unimaginable."

Yet four days after March 6, the French government banned all public meetings and ten days later forcibly confined people to their residences. By now, several billion people around the world have been locked down. Public meetings, including religious observances, are banned in most democracies. In many, people are not allowed to continue their economic activities. In several democracies people voluntarily subject their movements to geolocalization and in some they are forced to do so. Impending elections have been postponed in several countries (Global overview of COVID-19 impact on elections 2020). Parliaments delegate powers to the executives and suspend their deliberative activities. Judicial proceedings are being put on hold.

The measures adopted around the world include schools closings, banning all non- 
essential commerce and services, bans on all public meetings, including religious observances, confinement to places of residence, and shutting all non-essential production. ${ }^{3}$ These measures differ in the extent to which they violate rights and the extent to which they are unprecedented. School closings prevent some parents (particularly single mothers) from exercising economic activities and deprive some children of education (Alon et al. 2020). But temporary school closings, such as "snow days," are routine, and academic year calendars are not rooted in constitutions and typically not even set by laws. Prohibitions of public meetings typically occur either in the face of natural disasters or of civil unrest, but tend to be local and short-lived. Blanket bans on meetings violate the right to associate and, when they include religious observances, the freedom of religion. Obligatory confinement to places of residence, to which we refer as lockdown, violates a fundamental right. Partial or targeted restrictions of movement, such as curfews, bans on vehicle circulation, cordons of particular localities, or closings of some internal routes, are routinely applied in conditions of natural disasters or civil unrest. But lockdowns, even if always accompanied by lists of exceptions concerning "essential workers," are general and indiscriminate. They are not limited to obligatory isolation of people arriving from abroad, of people diagnosed as positive and those with whom they have been in contact: such measures constitute "quarantine" but not lockdown. Defined in such narrow terms, lockdowns are historically unprecedented. Finally, compulsory shutdown of all non-essential productive activities is again without precedent. Although not all constitutions explicitly grant the right to engage in them, ${ }^{4}$ they can be thought to be implied by the rights to hold and use property. And they are most costly economically.

We make no claims about the effects of these measures on individual behavior. ${ }^{5}$ The effect of a ban on public gatherings, a 17:00 to 6:00 curfew, combined with closing non-essential business, and accompanied by "encouragement," "recommendation," or "urging" that people remain home, as in Angola or the Dominican Republic, is likely to have an effect identical to compulsory lockdown. ${ }^{6}$ After all, where can people go when they have nowhere to go? But even if governments take actions that physically restrict individual choice, compliance with government advice is still left to individual discretion, while compulsory measures eliminate it. Governments that introduce compulsory

\footnotetext{
${ }^{3}$ Many countries also adopted measures to mitigate economic effects, see Elgin, Basburg, and Yalaman (2020).

${ }^{4}$ In the data file by Elkins, Ginsburg, and Melton (2020), 29 percent of constitutions provide for the right to establish and conduct business firms and 38 percent to choose occupations.

${ }^{5}$ Hsiang et al. (2020) found that social distancing measures had a powerful effect on reducing the spread of infections in six countries.

${ }^{6}$ Gupta et al. (2020) found that in the U.S. compulsory social distancing measures had little effect on mobility, while early information did affect it. Chudik, Pesaran, and Rebucci (2020), however, learned that in China mandatory measures were effective, while voluntary compliance had effects only at the peak of the epidemic. Barrios et al. (2020) found that voluntary compliance was higher in US localities and European regions with higher civic capital, while Briscese et al. (2020) discovered that it increases with information and persuasion. Finally, Argente, Hsieh, and Lee (2020) also learned that information was very important in South Korea.
} 
measures are aware that they are violating rights: several decrees and declarations motivating these measures often explicitly cite the rights that are being violated and provide legal justification for abrogating them.

One should expect, therefore, that under the same conditions governments in societies which put a higher value on safeguarding rights should be more hesitant to take compulsory measures that violate them. That this is what in fact occurred is evident at a first glance. Figure 1 tells most of the story. In this figure four measures are ordered as a "severity" scale, which takes school closing as least severe, bans on public meetings as more severe, lockdowns as even more, and closing of all non-essential productive activities as most. Severity constitutes a scale in the sense that it was rare that a government would adopt a more severe measure if it had not adopted a less severe one: this pattern holds for 97.4 percent of all observations. The severity of measures in place between January 1 and April 30, 2020 is shown as a function of the daily cumulative death rates attributed to the COVID in the population. The announced numbers of deaths are almost certainly inaccurate, but these were the numbers that were known at the time, so they are to what governments and publics were reacting. ${ }^{7}$ Using the absolute daily number of deaths, the absolute number of cumulative deaths, or the rate of daily deaths in the population changes little.

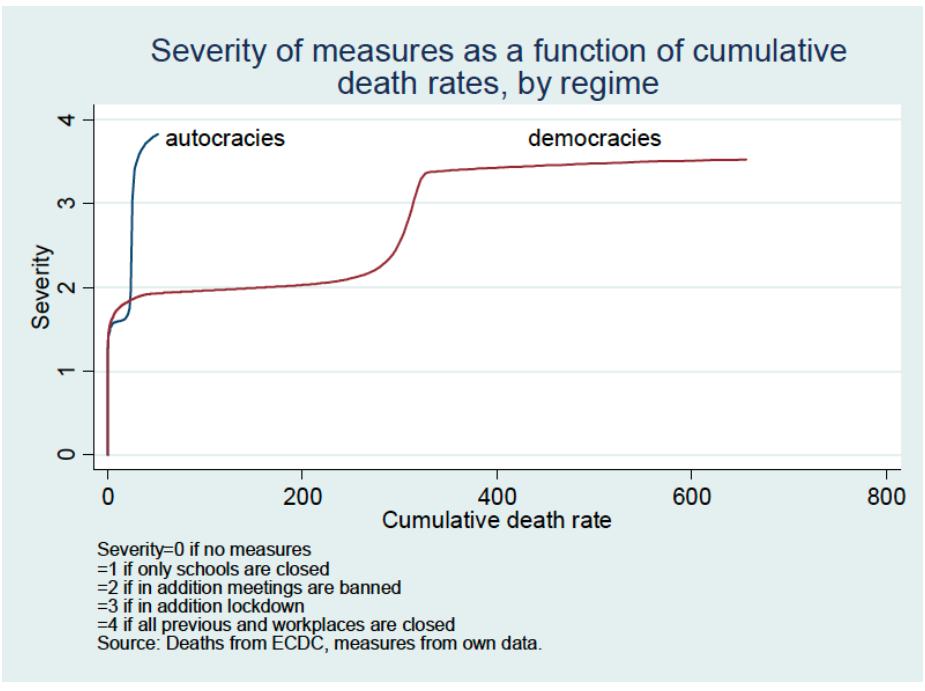

Figure 1

All countries closed schools almost as soon as the news about the impending pandemic spread out of China, many before the first death occurred. Indeed, school closings can be treated as a placebo test. The fact that regimes do not differ with regard to the least obtrusive measure eliminates the hypothesis that autocracies are just generally

\footnotetext{
${ }^{7}$ Some governments did manipulate the numbers, without themselves knowing what they were: Wuhan is a prominent example and so is the state of Florida.
} 
more prepared to take any kind of action. ${ }^{8}$ Banning meetings is ambivalent in that many autocracies did not have to formally ban them because they were previously illegal. In turn, while autocracies almost immediately adopted more rights-constraining measures, democracies waited for many more deaths to accumulate before doing the same.

This summary picture is disaggregated among particular measures in Figure 2, which shows the proportion of countries in each type of regime that adopted and maintained a particular measure, again as a function of cumulative death rates.

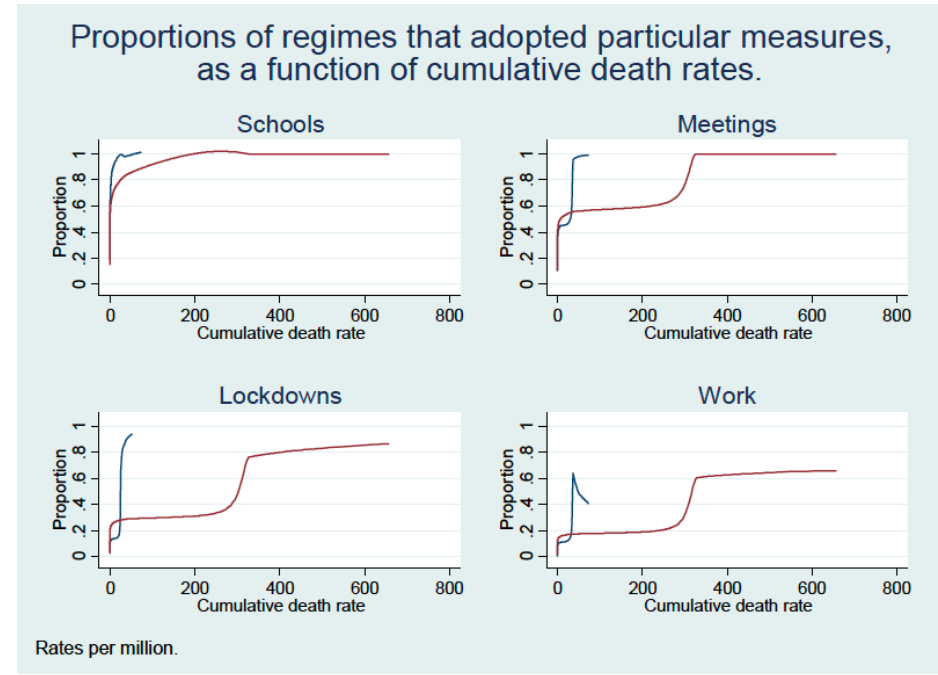

Figure 2

These pictures show both when, in terms of average cumulative death rates, the particular measures were adopted and whether they were maintained as the pandemic evolved. The initial exposure to the pandemic depended on the intensity of contacts with countries where it had already erupted, so that the dates when first deaths occurred vary across countries. Outside China, the first death occurred in the Philippines on February 2, the first European one in France on February 15, the first in Sub-Saharan Africa in Burkina Faso on March 19, and the first on a small island in Cape Verde on March 25. Moreover, 42 of the 185 countries for which data are available did not experience any deaths before May 1. In turn, to the extent that the particular measures affected the dynamic of the pandemic, the death rates subsequent to their adoption are endogenous: they depend on how early the measures were taken and on their marginal effectiveness. Thus, during the period preceding May 1 the death rate in no autocracy exceeded 73 per million while those in democracies reached 657 .

\footnotetext{
${ }^{8}$ Cronert (2020) finds that democracies closed schools earlier than autocracies. However, he maps school closings on known cases, rather than deaths, and cases are highly sensitive to the intensity of testing.
} 
To distinguish the moments when the measures were adopted from the subsequent evolution of the pandemic, Table 1 shows the cumulative death rates at the date when each of them was initiated.

Table 1 Average cumulative death rates on the day when particular measures were introduced, by regime.

\begin{tabular}{lccc}
\hline \hline Measures & Autocracy & Democracy & Not adopted $^{\mathrm{a}}$ \\
\hline \hline Schools & 0.10 & 0.08 & 0 \\
Meetings & 0.52 & 0.65 & 37 \\
Lockdowns & 0.87 & 9.08 & 85 \\
Work & 1.57 & 20.95 & 136 \\
\hline N & 60 & 125 & \\
...with deaths & 43 & 100 & \\
\hline \hline
\end{tabular}

a For those countries which did not introduce a particular measure before May 1, we take the cumulative death rate as of April 30, which is our last day of observation.

Again, the speed with which regimes closed schools is identical, while the delay of democracies in introducing lockdowns and closing work is notable.

We have thus learned that democracies were more hesitant to introduce measures that violated rights than autocracies. This is, however, not yet the entire story: the reaction among democracies was highly heterogenous and the democracies that reacted most slowly to the growing number of deaths were predominantly the oldest, the most established ones, those with the highest scores on all kinds of indices. They are the ones which either did not go beyond banning public meetings or began to lock down only when the number of cumulative deaths was already large. One among many ways to summarize this information is presented in Figure 3, which portrays the cumulative death rates at which lockdowns and work closings were first adopted as a function of the $\mathrm{V}$-dem polyarchy score. 


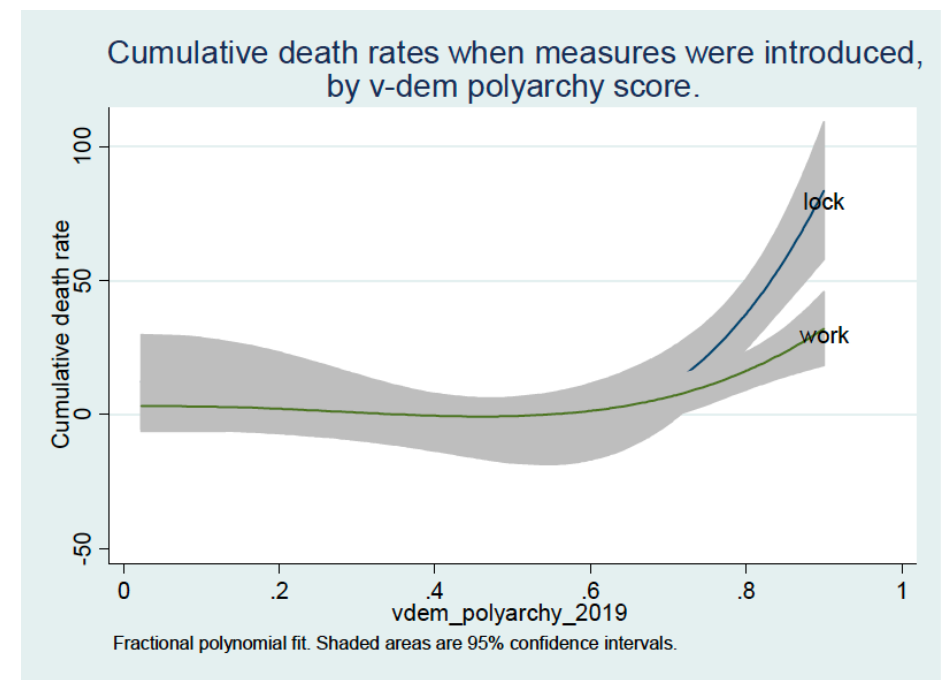

Figure 3

While details are many, this is sufficient to draw conclusions. We see that democracies reacted slower to the crisis and that the most solidly democratic among them were particularly disinclined to react. Governments may not want to abrogate rights because they share the respect for them. Political considerations are also at play. Such measures provide fodder for partisan opposition to claim that governments are abusing their powers. Thus, legal acts authorizing exceptional measures often go at length in both admitting that entrenched rights are being violated and citing legal justification that enables abrogating them. ${ }^{9}$ They claim that the measures are "necessary and

\footnotetext{
${ }^{9}$ Here, for example, is the justification of the Decree 297/2020 of the Presidency of the Argentine Republic, on March 3, 2020: "CONSIDERING: That Article 14 of the National Constitution establishes that 'all the inhabitants of the Nation enjoy the following rights in accordance with the laws that regulate their exercise; namely: to work and exercise any lawful industry; to navigate and trade; to petition to the authorities, to enter, stay, transit and leave the Argentine territory ...' That, although it turns out to be one of the fundamental pillars guaranteed in our legal system, it is subject to limitations for reasons of public order, security and public health. In effect, the International Covenant on Civil and Political Rights (ICCPR) includes in its Article 12.1 the right to '... move freely ...', and Article 12.3 establishes that the exercise of the rights established by it 'may not be object of restrictions unless these are provided for in the law, are necessary to protect national security, public order, public health or morals or the rights and freedoms of third parties, and are compatible with the other rights recognized in the present Covenant.' That, in the same sense, the American Convention on Human Rights establishes in its Article 22 subsection 3 that the exercise of the rights to move and reside in a State established in Article 22.1 ‘.. cannot be restricted except by virtue of a law, to the extent necessary in a democratic society, to prevent criminal offenses or to protect national security, public safety or order, public morals or public health, or the rights and freedoms of others.' That, in this sense, it has been said that, '... the scope of action of the health police is very broad, its relevance to everything that may affect the life and health of people, especially the fight against diseases of all kinds, to which effect preventive duties are imposed, to prevent the appearance and spread of diseases - for example ... isolation or quarantine ...' (The Power of the Police and Health Police. Scope of State Responsibility in Issues of State Intervention - Public Services. Power of Police and Development, Ed.
} 
proportional" and set terminal dates for their application. ${ }^{10}$ Moreover, governments dread being alarmist, taking harsh measures and seeing the danger dissipate. ${ }^{11}$ Hence, democratic governments may have to wait for observable signs of the danger in order to persuade people that measures restricting liberties and causing economic harm are necessary.

We attribute the reluctance of democracies in general and more narrowly of the oldest among them to their respect for rights. Yet democracies differ from autocracies in several other aspects. They include countries with the highest non-oil derived per capita incomes, countries with best medical infrastructure, and with the least painful experience of earlier epidemics. Below we show that the delay in their reactions is still detectable once these factors are taken into account. Yet we are aware that other interpretations are possible. The list of countries in which governments did not institute nationwide lockdowns or shut down work includes the United States under Trump and Brazil under Bolsonaro, neither of whom is distinguished by respecting rights. But it also includes, in ascending order of cumulative death rates as of April 30, Iceland, Finland, Norway, Germany, Canada, Switzerland, Sweden, and the Netherlands. In turn, twelve countries that were members of the OECD as of 1990, which we take as the most established democracies, instituted nationwide lockdowns when the cumulative rates were very low, Denmark and New Zealand before any deaths were reported. Hence, some factors we do not observe must be responsible for this heterogeneity among democracies. Whether it is respect for rights, aversion to mortality, some unobserved aspects of political situation, or just idiosyncrasies of political leaders remains mysterious.

Yet what we find remarkable is not that democracies were slow in responding to the crisis and not even that some of them never adopted lockdown or work closing, but that several among the most advanced democracies did end up adopting all the measures that violated basic rights, the measures used by autocracies. Among the twenty-three advanced democracies, sixteen installed lockdowns and ten went on to shut work. Their list includes most of the oldest and most liberal democracies in the world: Denmark, France, Ireland, New Zealand, the United Kingdom, and parts of the United States. The deep lesson we see is that when death looms, other values retract. What it means about us as human beings is profound. Physical survival is an

RAP, Bs. As., 2011, p. 100). That the measures established in this decree are essential, reasonable and proportionate in relation to the threat and the health risk we face."

${ }^{10}$ Thus Nicole Belloubet, the French Minister of Justice emphasized that the law of March 23, which gave the government the power to rule by decree, was designed only to "confront the consequences of propagation of the epidemic of Covid-19 and the consequences of measures taken to limit this propagation. None of the other fundamental rights and counterbalances essential for democratic life is touched: freedom of expression, of communication, of information, and of criticizing remain the same as in ordinary times." (Le Monde 1 April 2020).

${ }^{11}$ In 2008 the French Ministry of Health spent 1.5 billion euros on swine-flu vaccines and, although only $8 \%$ of the French vaccinated, the epidemic never materialized, leading to an accusation of wasteful spending against the Minister, Roselyn Bachelot-Narqui. In 1996 the UK government ordered the slaughter of 6 million cows and the "mad cow" disease never materialized. 
imperative; everything else is a luxury. Patrick Henry's exhortation - "Give me liberty or give me death" - appears as an aberration. We learn, as Justice Robert Jackson had it, that a constitution cannot be treated "as a suicide pact."

Given that democracies reacted slower but most eventually ended up doing the same as autocracies, it is tempting to blame democratic governments for causing unnecessary deaths. Decreasing the contact rate - the probability that someone infected encounters someone who is still susceptible — saves lives. Yet adopting compulsory restrictive measures under democracy requires political support and, before the danger becomes widespread and manifest, the level of support may not be sufficient for these measures to be politically palatable and enforceable. We would certainly not want to give up our rights in normal times, so ideally, we would instantaneously adjust to emergencies, strictly limit the exceptional measures to those that are necessary and proportional, and revoke them as soon as the danger wanes. The institution of dictatorship in Ancient Rome was designed to enable such adjustments. But the question always remains about what circumstances justify invoking an emergency, and the danger remains that the measures would extend beyond those necessary and that the return to normal would extend beyond the time required (Ginsburg and Versteeg 2020); (Aguillar Rivera 2020). Whether or not democratic constitutions provide for exceptional states - most do a recognition that the circumstances call for some rights to be violated is not easy to swallow. Hence, perhaps the damage caused by the slow reaction of democracies to the emergency is the cost of enjoying rights in normal times, which autocracies do not.

\section{Lockdowns and Work Closings by Regimes}

Because the antecedent conditions may have different effects in different groups of countries, to avoid introducing all the interaction terms, we analyze the reactions of governments separately for each regime and then focus on the heterogeneity among democracies. Preliminary analysis (not shown) shows that the timing of the introduction of these measures depended not only on the antecedent conditions but also on the spread of the pandemic, whether it is measured by the absolute number of daily deaths, the absolute number of cumulative deaths, the daily death rate in the population, or the cumulative death rate in the population. We present the results only for the daily deaths and for the cumulative death rate. They are derived from survival models using the Weibull distribution. ${ }^{12}$

\footnotetext{
${ }^{12}$ The Cox model generates results almost identical to Weibull but is inferior by the $\log \mathrm{L}$ and AIC criteria. Models based on lognormal distributions also generate results qualitatively similar to Weibull and they tend to outperform the Weibull model for lockdowns and underperform for work closings. Because the differences in the AIC criterion are not large, we decided to present the Weibull results throughout. For details, see the appendix. On choosing models, see Burnham and Anderson (2004).
} 


\subsection{Lockdowns}

Lockdown is a compulsory restriction on leaving places of residence, applied indiscriminately to everyone except specified categories of people (such as "essential workers") or specified purposes (such as shopping or recreation). Thus, we do not consider as lockdown instances in which the government urges, asks or invites people to stay home. Lockdown applies to persons, not to business establishments. Note importantly that it is possible for a lockdown to be in place and for people to be able to work. This is true when the exclusions to the ban on movements include travel to and from work. We do not observe whether an order was enforced.

Figure 4 shows the effect of different factors on the speed with which different countries adopted lockdowns, at least at a subnational levels.

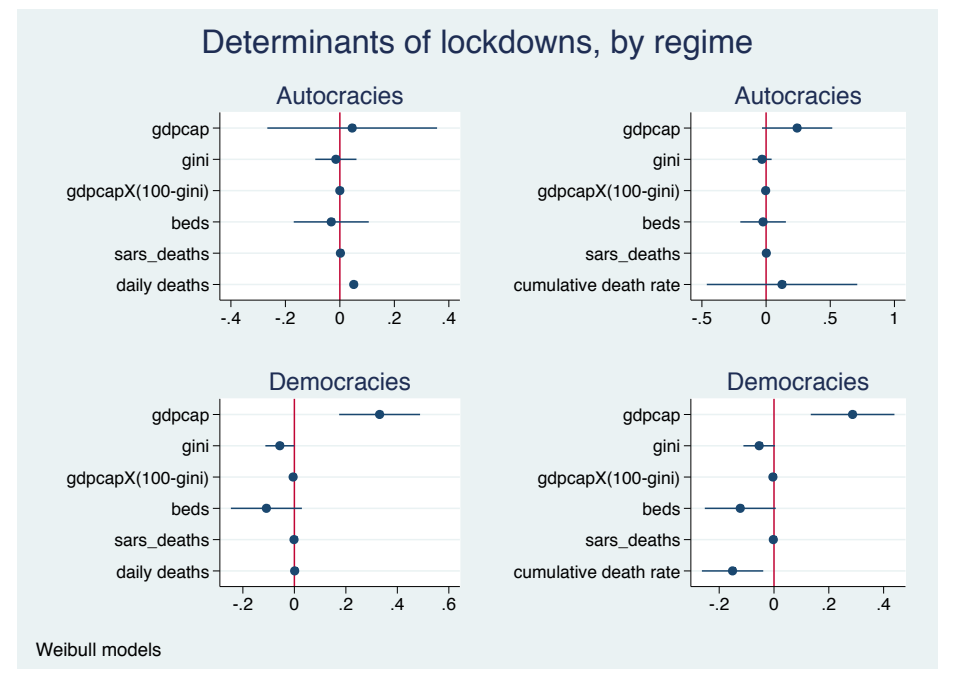

Figure 4

The economic conditions had no effect on instituting lockdown in autocracies, while they were highly important in democracies. In particular, democracies with high per capita incomes were more prone to introduce lockdowns, as were democracies with lower income inequality. Having more hospital beds made democracies more prone to tolerate the epidemic, while it did not matter in autocracies. Beds are the only aspect of health infrastructure that mattered in either regime: neither the density of nurses nor of physicians affected the lockdown decisions. Finally, the memory of SARS deaths made autocracies more vigilant, while it was less relevant for democracies, and the memory of MERS did not matter for either regime.

The reaction to the spread of the pandemic is complex. The absolute number of daily deaths had a powerful effect on instituting lockdowns in autocracies, while it did not affect this decision in democracies. In turn, the cumulative death rates played no role in autocracies while democracies did not lockdown even as these rates mounted. 
Summing these two facts together clearly indicates that democracies were slower to react both to the absolute and cumulative deaths caused by the pandemic. Hence, the slow reaction of democracies cannot be attributed to the antecedent conditions we considered. It must have been something else.

What is most perplexing is that democracies did not just react slower to the growth of cumulative death rates than autocracies: on average, they were more likely to delay lockdowns as deaths mounted. To understand this pattern, note that the responses of democracies were highly heterogeneous.

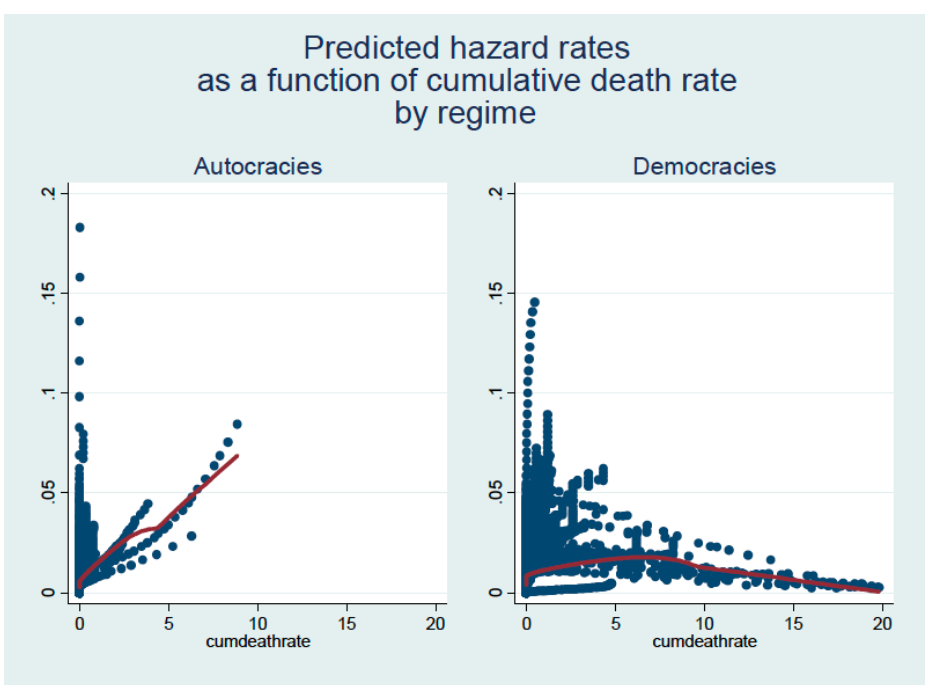

Figure 5

The negative slope of the hazard rates with regard to cumulative death rates is thus due to heterogeneity among democracies. Many democracies reacted to growing death rates in the same way as autocracies: either immediately instituting lockdowns or hesitating to do so but yielding in the face of manifest danger. But some democracies, and only democracies, stubbornly resisted locking down even when the cumulative death rates became large. Of the eighteen countries that did not institute a nationwide lockdown by April 30 with cumulative death rates over 20 per million, only Iran was an autocracy, while among the seventeen democracies which did not, ten were members of the OECD by 1990 .

\subsection{Work closings}

This variable indicates closings of non-essential offices, production, and construction sites. Note that it applies only to offices, production, and construction sites. Almost all countries - to our best knowledge all except Sweden — closed very early public spaces such as cafes, restaurants, department stores offering non-essential goods, barber shops, brothels (as in Bangladesh), etc. Such measures are not included as work closings. 
Analogously to the analysis of lockdowns, Figure 6 shows the effect of different factors on the speed with which different countries shut work, at least at a subnational levels.

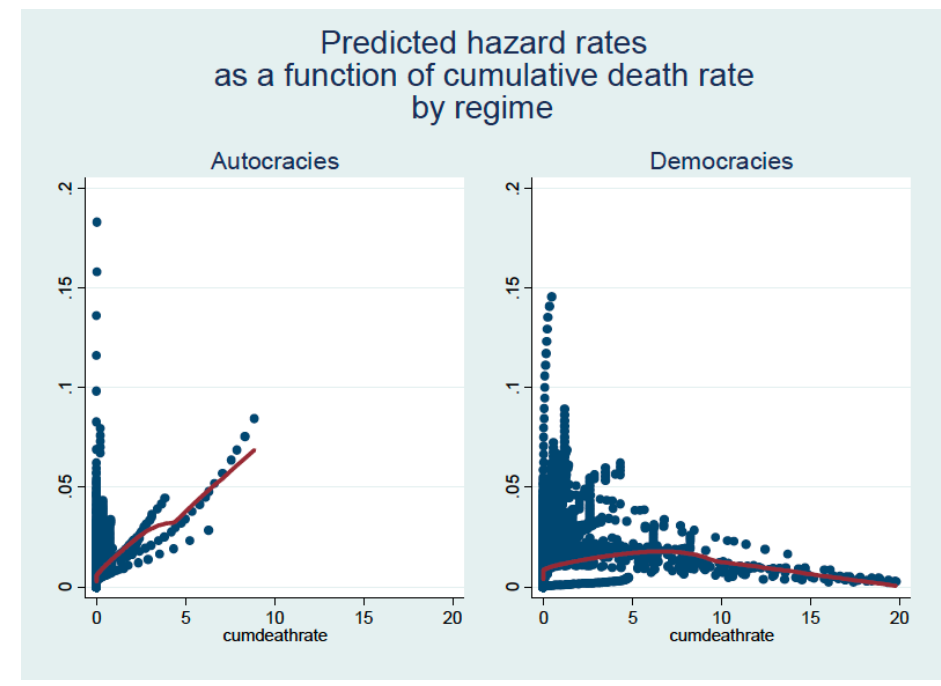

Figure 6

The results with regard to economic variables as well as with regard to density of hospital beds are similar to those of lockdowns: higher income and more equal democracies were more likely to shut down work and those with more beds less likely to do it. The major difference is that autocracies were responsive not only to absolute numbers of daily deaths but also to the cumulation in the population, while democracies were responsive to daily deaths (the point estimate of the hazard rate is 1.0045 , with confidence interval $[1.0013,1.0076])$ but oblivious to their cumulation.

The patterns of heterogeneity are again similar to those of lockdown. The probability of shutting work rose sharply in autocracies and some democracies as deaths accumulated. But in some democracies it remained almost constant in spite of the growing death rates. 


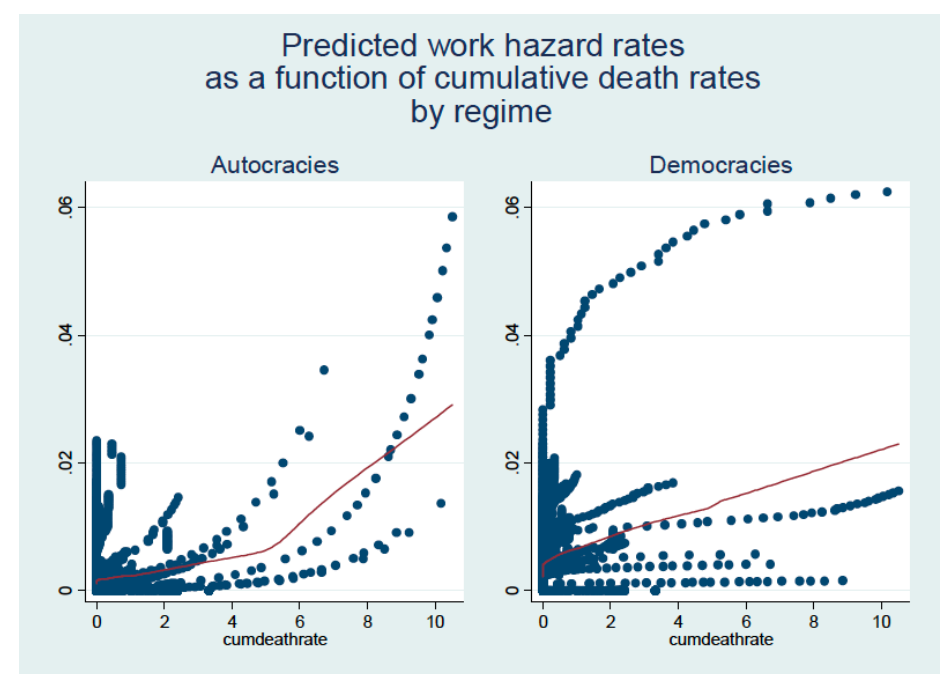

Figure 7

\section{Conclusions}

Some democratic governments, notably Denmark and New Zealand, were willing from the beginning to do everything possible to prevent the damage that would be caused by the pandemic. Some - Italy, France, Spain, and the United Kingdom are examples - were hesitant but yielded when deaths began to mount. Notably, these two postures were also present among autocracies. But several democratic governments must have decided to ride out the pandemic and stuck to their decisions even as cumulative death rates became large: in order of descending rates as of April 30, among the countries that were members of the OECD in 1990 these were the Netherlands, Sweden, Switzerland, Norway, Finland, Iceland, and Japan. Bear in mind that these differences are not due to per capita income, inequality, or medical preparedness. Perhaps, then, the slower reaction of democracies to the impending danger was on average due to their hesitation to abrogate important rights.

This explanation, however, does not suffice to elucidate the heterogeneity among democracies, including the most established ones. There is no reason to think that Danes are less respectful of rights than Swedes: In a study conducted in 21 members of the European Union toward the end of the period we study (Zalcr and Maillard 2020, 77-78), between April 23 and May 1, the proportion of respondents who thought that "The fight against the coronavirus pandemic justifies recent limitations to my individual freedom" ranged between 50 and 81 percent, with a weighted average of 68 percent. Positive responses were almost identical in the countries that did and did not adopt strict measures: 79 percent in Portugal, which did, and 78 percent in Finland, which did not; 72 percent in Denmark, which did, and respectively 72 and 71 percent in Sweden and the Netherlands, which did not. Hence, popular attitudes toward limitations to individual freedoms, at least as assessed ex-post, do not explain the heterogeneity of 
responses to the pandemic.

Perhaps the most plausible explanation is that all democratic governments were hesitant to abrogate right but some were led to believe that letting the pandemic take its course, relying on "herd immunity" strategy, would result in fewer deaths in the long run. This was true of Sweden, where, in line with the country's rules for autonomous agencies, the management of the pandemic was left in the hands of the Public Health Agency, whose head, Anders Tegnell, declared: "Any country that believes it can keep it out will most likely be proven wrong at some stage. We need to learn to live with this disease..." (Interview with Kim Hjelmgaard in USA Today, April 28). It was true of the Netherlands, where the Prime Minister, Mark Rudde, invoking the advice he received from experts, also expressed the belief that taking severe measures is pointless, because "the virus could simply rear its head again once the measures were lifted.... Until a vaccine is available, coronavirus will continue to sweep the world, and it won't spare the Netherlands" (Address to the Nation, on March 16).

Finally, it is also possible that some unobserved aspects of political situations would explain the differences. We did examine the possibility that the reactions differed in federal as distinct from more centralized countries. We tried all kinds of indices of state capacity and of government political strength. We entertained the possibility that female chief executives were more likely to react. All to no avail: none of these factors explains the heterogeneity among democracies.

Hence, in the end, we have learned that democracies were slower to react to the pandemic and that democratic governments that did adopt restrictive measures were well aware that they are abrogating rights. But why some did and others did not we still cannot tell. 


\section{References}

Adolph, Christopher, Kenya Amano, Bree Bang-Jensen, Nancy Fullman, and John Wilkerson. 2020. "Pandemic politics: Timing state-level social distancing responses to COVID-19." University of Washington.

Aguillar Rivera, José Antonio. 2020. "El virus y la emergencia.” Nexos Mayo.

Alon, Titan M., Matthias Doepke, Jane Olmstead-Rumsey, and Michèle Tertilt. 2020. "The impact of COVID-19 on gender equality." NBER Working Paper 26947.

Alvarez, Fernando E., David O. Argente, and Francesco Lippi. 2020. "A simple planning problem for Covid-19 lockdown." NBER Working Paper 26981.

Argente, David O., Chang-Tai Hsieh, and Munseob Lee. 2020. "The cost of privacy: Welfare effect of the disclosure of COVID-19 cases." NBER Working Paper 27220.

Barrios, John M., Efraim Benmelech, Yael V. Hochberg, Paola Sapienza, and Luigi Zingales. 2020. "Civic Capital and Social Distancing during the Covid-19 Pandemic." NBER Working Paper 27320.

Barrios, John M., and Yael Hochberg. 2020. "Risk perception through the lens of politics in the time of the COVID-19 pandemic." NBER Working Paper 27009.

Briscese, Guglielmo, Nicola Lacetera, Mario Macis, and Mirco Tonin. 2020. "Complicance with COVID-19 social distancing measures in Italy: The role of expectations and duration." NBER Working Paper 26916.

Burnham, Kenneth P., and David R. Anderson. 2004. "Multimodel inference: Understanding AIC and BIC in model selection." Sociological Methods Research 33.

Cepaluni, Gabriel, Michael T. Dorsch, and Reka Branyiczki. 2020. "Political regimes and deaths in the early stages of the COVID-19 pandemic." Central European University, Budapest.

Chudik, Alexander, M. Hashem Pesaran, and Alessandro Rebucci. 2020. "Voluntary and mandatory social distancing: Evidence on COVID-19 exposure rates from Chinese provinces and selected countries." NBER Working Paper 27039.

Coibion, Olivier, Yuriy Gorodnichenko, and Michael Weber. 2020. "The cost of the covid-19 crisis: Lockdowns, macroeconomic expectations, and consumer spending." NBER Working Paper 27141.

Cronert, Axel. 2020. "Democracy, state capacity, and COVID-19 related school closures." Department of Government, Uppsala University. 
Eichenbaum, Martin S., Sergio Rebelo, and Mathias Trabandt. 2020. "The Macroeconomics of Epidemics." NBER Working Paper 26882.

Elgin, Ceyhun, Gokce Basburg, and Abdullah Yalaman. 2020. "Economic policy responses to a pandemic: Developing the COVID-19 economic stimulus index." Columbia University and Bogazici University.

Elkins, Zachary, Tom Ginsburg, and James Melton. 2020. "Characteristics of National Constitutions, Version 2.0." https://comparativeconstitutionsproject.org/downloaddata/.

Frey, Carl Benedikt, Chinchih Chen, and Giorgio Presidente. 2020. "Democracy, culture and contagion: Political regimes and countries responsiveness to Covid-19." Oxford Martin School, Oxford University.

Ginsburg, Tom, and Mila Versteeg. 2020. "Bindin the unbound executive: Checks and balances in times of pandemic." Public Law and Legal Theory Research Paper Series 2020-52.

Global overview of COVID-19 impact on elections. 2020. https://www.idea.int/newsmedia/multimedia-reports/global-overview-covid-19-impact-elections.

Gupta, Sumedha, Thuy D. Nguyen, Felipe Lozano Rojas, Shyam Raman, Byungkyu Lee, Ana Bento, Kosali I. Simon, and Coady Wing. 2020. "Tracking public and private responses to the COVID-19 epidemic: Evidence from state and local government actions." NBER Working Paper 27027.

Hsiang, Solomon, Daniel Allen, Sebastien Annan-Phan, Kendon Bell, Ian Bolliger, Trinetta Chong, Hannah Druckenmiller, Luna Yue Huang, Andrew Hultgren, Emma Krasovich, Peiley Lau, Jaecheol Lee, Esther Rolf, Jeanette Tseng, and Tiffany Wu. 2020. "The effect of large-scale anti-contagion policies on the COVID-19 pandemic." Nature Published online June 8,2020 (June 8).

Jones, Callum J., Thomas Philippon, and Venky Venkateswaran. 2020. "Optimal mitigation policies in a pandemic: Social distancing and working from home." NBER Working Paper 26984.

Spence, Michael, and Chen Long. 2020. "Mapping the pandemic economy." https://www.project-syndicate.org/onpoint/pandemic-economy-data-visualizationsby-michael-spence-and-chen-long-2020-06?barrier=accesspaylog.

Zalcr, Julien, and Robin Maillard. 2020. Uncertainty/EU/Hope: Public Opinion in Times of Covid-19. Brussels, Belgium: Public Opinion Monitoring Unit, DirectorGeneral for Communication, European Parliament. 


\section{Appendices}

\section{Background}

The data include 191 countries from January 1 through April 30, 2020. The reason for choosing this terminal date is that by then all governments that would lockdown we observed was on April 17, the last ban on meetings on April 18, and the last work closure on April 17. Conversely, almost no relaxation of the previously adopted measures occurred before May 1. Table A1 shows the means of antecedent variables by regime. Note that autocracies include some oil countries with very high incomes.

Table A.1 Conditions antecedent to the pandemic by regime

\begin{tabular}{lcc}
\hline Regime & Autocracy & Democracy \\
\hline $\mathrm{N}$ & 60 & 125 \\
gdpcap $^{\mathrm{a}}$ & 17,948 & 19,252 \\
urban & 61.5 & 60.9 \\
gini & 39.7 & 38.1 \\
beds per 1,000 & 2.52 & 3.24 \\
nurses per 1,000 & 2.99 & 4.56 \\
physicians per 1,000 & 1.19 & 1.87 \\
sars deaths & 25.1 & 1.01 \\
mers deaths & 18.4 & 0.38 \\
\hline
\end{tabular}

a As of the latest date the data are available. Sources are in the Codebook.

\section{Alternative models}

Here we show detailed results of statistical analyses for the four death variables, for the Weibull, and lognormal distributions, and robustness checks using alternative scales of democracy. The Cox model generates results qualitatively similar to Weibull but is inferior to other model by the log likelihood and Akaike's information criterion (AIC) standards. 
Table A.2 Survival Analysis of Lockdowns (Democracy)

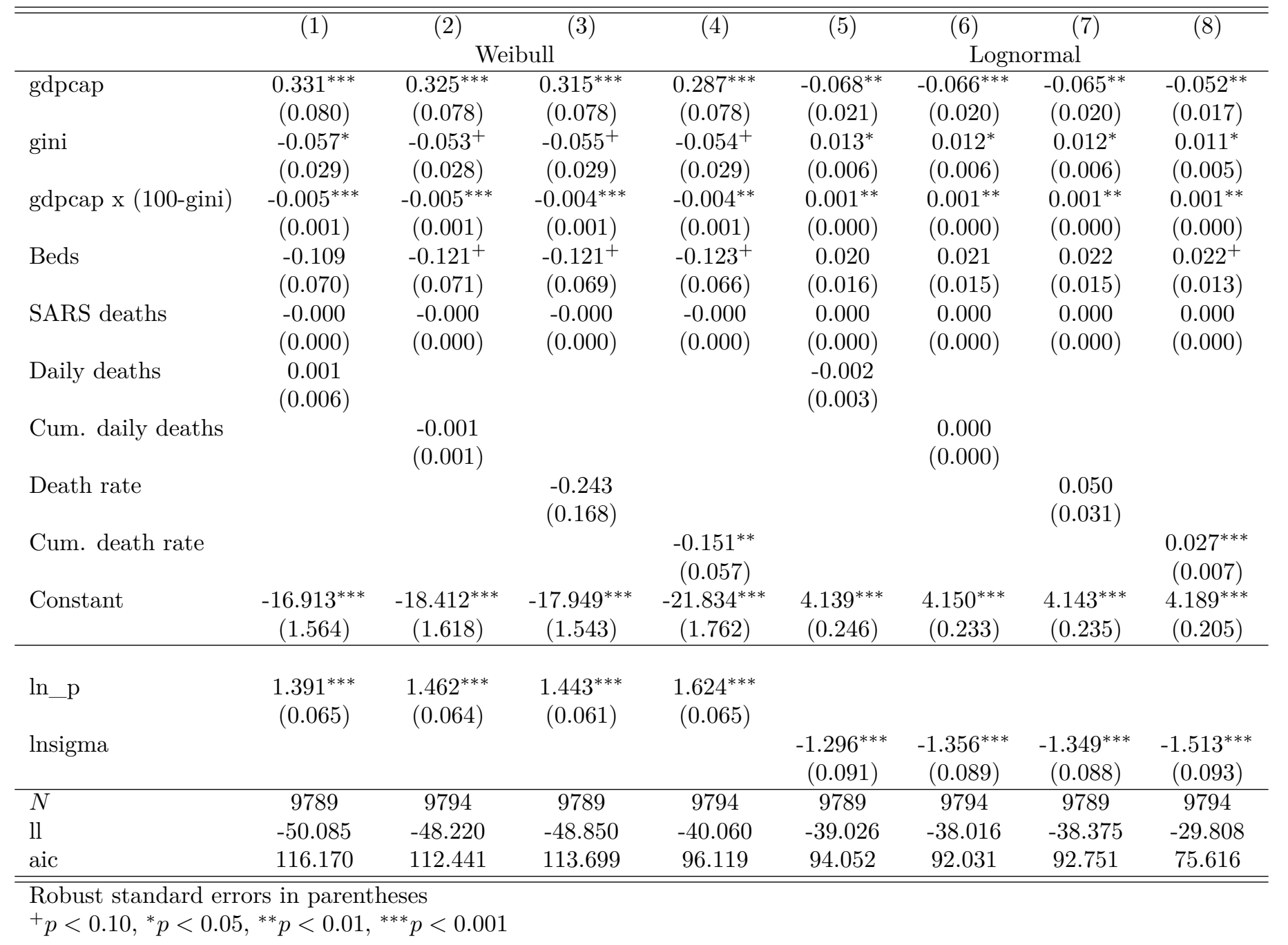


Table A.3 Survival Analysis of Lockdowns (Autocracy)

\begin{tabular}{|c|c|c|c|c|c|c|c|c|}
\hline & (1) & $(2)$ & (3) & (4) & $(5)$ & (6) & (7) & (8) \\
\hline & \multicolumn{4}{|c|}{ Weibull } & \multicolumn{4}{|c|}{ Lognormal } \\
\hline gdpcap & $\begin{array}{c}0.045 \\
(0.159)\end{array}$ & $\begin{array}{c}0.064 \\
(0.153)\end{array}$ & $\begin{array}{l}0.249^{+} \\
(0.136)\end{array}$ & $\begin{array}{l}0.242^{+} \\
(0.140)\end{array}$ & $\begin{array}{l}-0.000 \\
(0.035)\end{array}$ & $\begin{array}{l}-0.003 \\
(0.035)\end{array}$ & $\begin{array}{l}-0.031 \\
(0.033)\end{array}$ & $\begin{array}{l}-0.033 \\
(0.034)\end{array}$ \\
\hline gini & $\begin{array}{l}-0.015 \\
(0.039)\end{array}$ & $\begin{array}{l}-0.014 \\
(0.039)\end{array}$ & $\begin{array}{l}-0.033 \\
(0.039)\end{array}$ & $\begin{array}{l}-0.032 \\
(0.038)\end{array}$ & $\begin{array}{c}0.003 \\
(0.008)\end{array}$ & $\begin{array}{c}0.003 \\
(0.008)\end{array}$ & $\begin{array}{c}0.006 \\
(0.008)\end{array}$ & $\begin{array}{c}0.006 \\
(0.008)\end{array}$ \\
\hline gdpcap x (100-gini) & $\begin{array}{l}-0.000 \\
(0.002)\end{array}$ & $\begin{array}{l}-0.000 \\
(0.002)\end{array}$ & $\begin{array}{l}-0.003 \\
(0.002)\end{array}$ & $\begin{array}{l}-0.003 \\
(0.002)\end{array}$ & $\begin{array}{l}-0.000 \\
(0.001)\end{array}$ & $\begin{array}{l}-0.000 \\
(0.001)\end{array}$ & $\begin{array}{c}0.000 \\
(0.000)\end{array}$ & $\begin{array}{c}0.000 \\
(0.001)\end{array}$ \\
\hline Beds & $\begin{array}{c}-0.032 \\
(0.070)\end{array}$ & $\begin{array}{l}-0.035 \\
(0.070)\end{array}$ & $\begin{array}{l}-0.033 \\
(0.077)\end{array}$ & $\begin{array}{l}-0.023 \\
(0.091)\end{array}$ & $\begin{array}{c}0.011 \\
(0.017)\end{array}$ & $\begin{array}{c}0.011 \\
(0.017)\end{array}$ & $\begin{array}{c}0.007 \\
(0.017)\end{array}$ & $\begin{array}{c}0.007 \\
(0.018)\end{array}$ \\
\hline SARS deaths & $\begin{array}{c}0.000^{* * *} \\
(0.000)\end{array}$ & $\begin{array}{c}0.000^{* * *} \\
(0.000)\end{array}$ & $\begin{array}{c}0.000^{* * *} \\
(0.000)\end{array}$ & $\begin{array}{c}0.000^{* * *} \\
(0.000)\end{array}$ & $\begin{array}{c}-0.000^{* * *} \\
(0.000)\end{array}$ & $\begin{array}{c}-0.000^{* * *} \\
(0.000)\end{array}$ & $\begin{array}{c}-0.000^{* * *} \\
(0.000)\end{array}$ & $\begin{array}{c}-0.000^{* * *} \\
(0.000)\end{array}$ \\
\hline Daily deaths & $\begin{array}{c}0.051^{* * *} \\
(0.006)\end{array}$ & & & & $\begin{array}{c}-0.017^{* *} \\
(0.006)\end{array}$ & & & \\
\hline Cum. daily deaths & & $\begin{array}{c}0.005 \\
(0.004)\end{array}$ & & & & $\begin{array}{c}-0.002 \\
(0.001)\end{array}$ & & \\
\hline Death rate & & & $\begin{array}{l}2.618^{+} \\
(1.577)\end{array}$ & & & & $\begin{array}{l}-0.625 \\
(0.442)\end{array}$ & \\
\hline Cum. death rate & & & & $\begin{array}{c}0.124 \\
(0.299)\end{array}$ & & & & $\begin{array}{c}-0.084 \\
(0.091)\end{array}$ \\
\hline Constant & $\begin{array}{c}-21.450^{* * *} \\
(2.326)\end{array}$ & $\begin{array}{c}-20.443^{* * *} \\
(2.405)\end{array}$ & $\begin{array}{c}-20.668^{* * *} \\
(2.647)\end{array}$ & $\begin{array}{c}-20.718^{* * *} \\
(3.142)\end{array}$ & $\begin{array}{c}4.704^{* * *} \\
(0.327) \\
\end{array}$ & $\begin{array}{c}4.693^{* * *} \\
(0.326) \\
\end{array}$ & $\begin{array}{c}4.608^{* * *} \\
(0.312) \\
\end{array}$ & $\begin{array}{c}4.595^{* * *} \\
(0.319) \\
\end{array}$ \\
\hline $\ln \_p$ & $\begin{array}{c}1.496^{* * *} \\
(0.099)\end{array}$ & $\begin{array}{c}1.445^{* * *} \\
(0.120)\end{array}$ & $\begin{array}{c}1.487^{* * *} \\
(0.108)\end{array}$ & $\begin{array}{c}1.489^{* * *} \\
(0.143)\end{array}$ & & & & \\
\hline lnsigma & & & & & $\begin{array}{c}-1.252^{* * *} \\
(0.121)\end{array}$ & $\begin{array}{c}-1.247^{* * *} \\
(0.121)\end{array}$ & $\begin{array}{c}-1.266^{* * *} \\
(0.122)\end{array}$ & $\begin{array}{c}-1.239^{* * *} \\
(0.124)\end{array}$ \\
\hline$N$ & 4543 & 4550 & 4422 & 4429 & 4543 & 4550 & 4422 & 4429 \\
\hline ll & -18.377 & -20.591 & -18.904 & -19.871 & -16.676 & -17.746 & -16.955 & -17.219 \\
\hline aic & 50.754 & 55.182 & 51.808 & 53.742 & 47.352 & 49.492 & 47.910 & 48.437 \\
\hline
\end{tabular}

Robust standard errors in parentheses

${ }^{+} p<0.10,{ }^{*} p<0.05,{ }^{* *} p<0.01,{ }^{* * *} p<0.001$ 
Table A.4 Survival Analysis of Work Closings (Democracy)

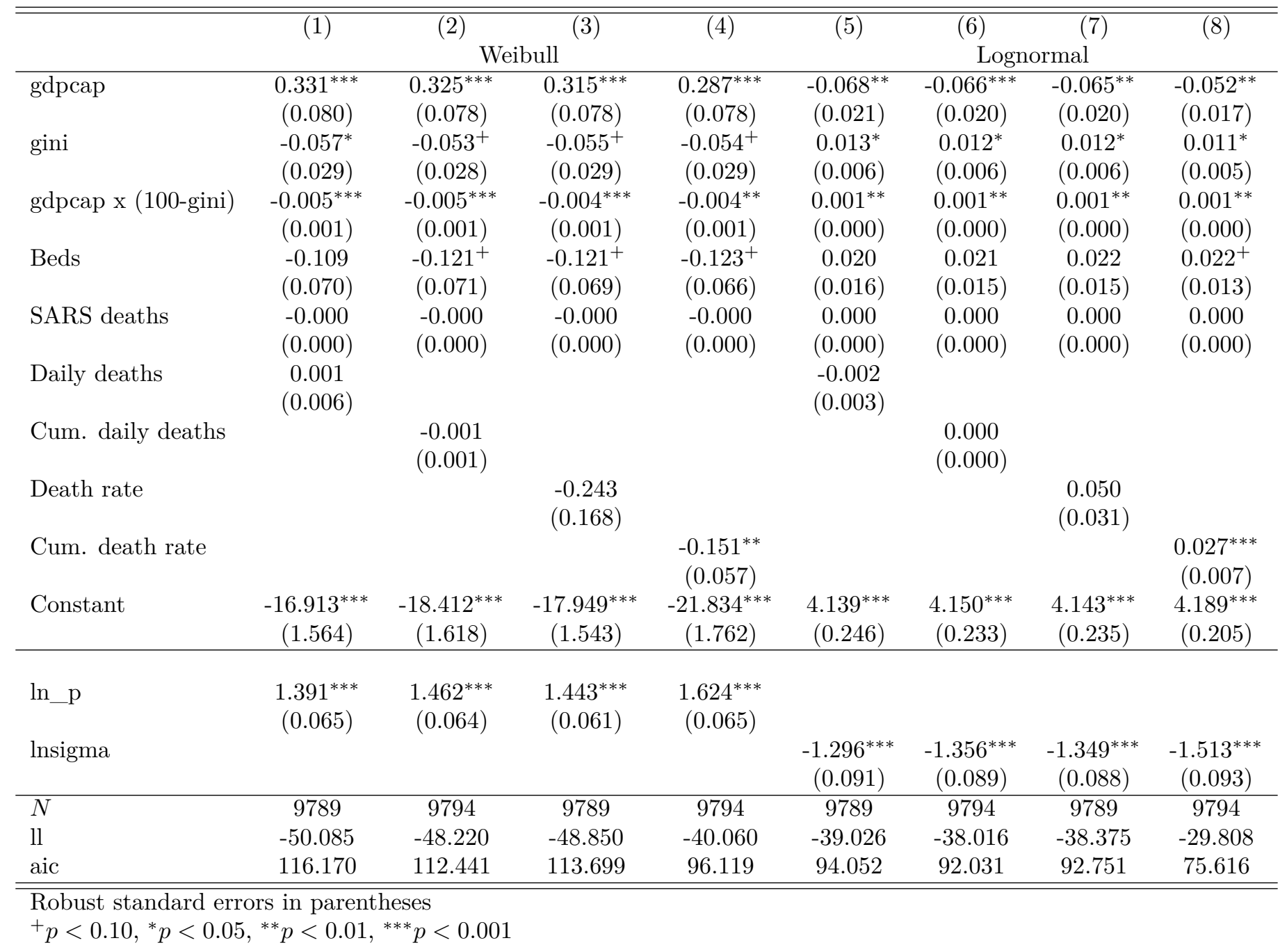


Table A.5 Survival Analysis of Work Closings (Autocracy)

\begin{tabular}{|c|c|c|c|c|c|c|c|c|}
\hline & (1) & $(2)$ & $(3)$ & (4) & (5) & (6) & (7) & (8) \\
\hline & \multicolumn{4}{|c|}{ Weibull } & \multicolumn{4}{|c|}{ Lognormal } \\
\hline \multirow[t]{2}{*}{ gdpcap } & 0.209 & 0.213 & $0.407^{+}$ & $0.446^{+}$ & & -0.052 & -0.109 & $\begin{array}{l}-0.129 \\
\end{array}$ \\
\hline & $(0.195)$ & $(0.216)$ & $(0.210)$ & $(0.237)$ & & $(0.061)$ & $(0.073)$ & $(0.081)$ \\
\hline \multirow[t]{2}{*}{ gini } & 0.066 & 0.064 & 0.027 & 0.042 & & -0.014 & -0.006 & -0.005 \\
\hline & $(0.056)$ & $(0.055)$ & $(0.049)$ & $(0.049)$ & & $(0.015)$ & $(0.014)$ & $(0.015)$ \\
\hline \multirow[t]{2}{*}{ gdpcap x (100-gini) } & -0.003 & -0.003 & $-0.006^{*}$ & $-0.007^{+}$ & & 0.001 & 0.002 & 0.002 \\
\hline & $(0.003)$ & $(0.003)$ & $(0.003)$ & $(0.004)$ & & $(0.001)$ & $(0.001)$ & $(0.001)$ \\
\hline \multirow[t]{2}{*}{ Beds } & -0.217 & -0.202 & -0.043 & -0.060 & & 0.033 & 0.015 & 0.019 \\
\hline & $(0.183)$ & $(0.252)$ & $(0.105)$ & $(0.114)$ & & $(0.036)$ & $(0.031)$ & $(0.035)$ \\
\hline \multirow[t]{2}{*}{ SARS deaths } & $-0.000^{* * *}$ & $-0.000^{* * *}$ & $-0.000^{* * *}$ & $-0.000^{* * *}$ & & $0.000^{* * *}$ & $0.000^{* * *}$ & $0.000^{* * *}$ \\
\hline & $(0.000)$ & $(0.000)$ & $(0.000)$ & $(0.000)$ & & $(0.000)$ & $(0.000)$ & $(0.000)$ \\
\hline \multirow[t]{2}{*}{ Daily deaths } & $0.055^{* *}$ & & & & & & & \\
\hline & $(0.018)$ & & & & & & & \\
\hline \multirow[t]{2}{*}{ Cum. daily deaths } & & 0.005 & & & & -0.002 & & \\
\hline & & $(0.003)$ & & & & $(0.002)$ & & \\
\hline \multirow[t]{2}{*}{ Death rate } & & & $3.698^{* *}$ & & & & -1.139 & \\
\hline & & & $(1.422)$ & & & & $(0.752)$ & \\
\hline \multirow[t]{2}{*}{ Cum. death rate } & & & & 0.419 & & & & -0.147 \\
\hline & & & & $(0.255)$ & & & & $(0.126)$ \\
\hline \multirow[t]{2}{*}{ Constant } & $-20.661^{* * *}$ & $-20.034^{* * *}$ & $-19.192^{* * *}$ & $-19.171^{* * *}$ & & $5.799^{* * *}$ & $5.488^{* * *}$ & $5.522^{* * *}$ \\
\hline & $(4.322)$ & $(4.543)$ & $(4.295)$ & $(4.237)$ & & $(0.607)$ & $(0.559)$ & $(0.614)$ \\
\hline \multirow[t]{2}{*}{$\ln \_p$} & $1.226^{* * *}$ & $1.191^{* * *}$ & $1.217^{* * *}$ & $1.173^{* * *}$ & & & & \\
\hline & $(0.160)$ & $(0.207)$ & $(0.199)$ & $(0.219)$ & & & & \\
\hline \multirow[t]{2}{*}{ lnsigma } & & & & & & $-0.771^{* * *}$ & $-0.823^{* * *}$ & $-0.744^{* * *}$ \\
\hline & & & & & & $(0.197)$ & $(0.206)$ & $(0.213)$ \\
\hline$N$ & 5060 & 5067 & 4939 & 4946 & & 5067 & 4939 & 4946 \\
\hline 11 & -13.974 & -15.590 & -14.024 & -14.538 & & -14.895 & -13.955 & -14.183 \\
\hline aic & 43.948 & 47.181 & 44.048 & 45.076 & & 45.789 & 43.911 & 44.365 \\
\hline
\end{tabular}

Robust standard errors in parentheses. Model (5) fails to converge.

${ }^{+} p<0.10,{ }^{*} p<0.05,{ }^{* *} p<0.01,{ }^{* * *} p<0.001$ 
Table A.6 Alternative Measures of Democracy on Lockdowns

\begin{tabular}{|c|c|c|c|c|c|c|c|c|}
\hline & $(1)$ & $\overline{(2)}$ & $\overline{(3)}$ & $\overline{(4)}$ & $(5)$ & 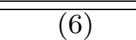 & $\overline{(7)}$ & $(8)$ \\
\hline & \multicolumn{4}{|c|}{ Weibull } & \multicolumn{4}{|c|}{ Log Normal } \\
\hline gdpcap & $\begin{array}{c}0.278^{* * *} \\
(0.078)\end{array}$ & $\begin{array}{c}0.271^{* * *} \\
(0.078)\end{array}$ & $\begin{array}{c}0.297^{* * *} \\
(0.074)\end{array}$ & $\begin{array}{c}0.297^{* * *} \\
(0.074)\end{array}$ & $\begin{array}{c}-0.051^{*} \\
(0.021)\end{array}$ & $\begin{array}{c}-0.049^{*} \\
(0.021)\end{array}$ & $\begin{array}{c}-0.057^{* *} \\
(0.020)\end{array}$ & $\begin{array}{c}-0.057^{* *} \\
(0.020)\end{array}$ \\
\hline gini & $\begin{array}{c}-0.055^{*} \\
(0.025)\end{array}$ & $\begin{array}{c}-0.053^{*} \\
(0.024)\end{array}$ & $\begin{array}{c}-0.059^{*} \\
(0.025)\end{array}$ & $\begin{array}{c}-0.059^{*} \\
(0.025)\end{array}$ & $\begin{array}{l}0.011^{*} \\
(0.005)\end{array}$ & $\begin{array}{l}0.011^{*} \\
(0.005)\end{array}$ & $\begin{array}{l}0.012^{*} \\
(0.005)\end{array}$ & $\begin{array}{l}0.012^{*} \\
(0.005)\end{array}$ \\
\hline gdpcap x (100-gini) & $\begin{array}{c}-0.004^{* * *} \\
(0.001)\end{array}$ & $\begin{array}{c}-0.004^{* * *} \\
(0.001)\end{array}$ & $\begin{array}{c}-0.004^{* * *} \\
(0.001)\end{array}$ & $\begin{array}{c}-0.004^{* * *} \\
(0.001)\end{array}$ & $\begin{array}{l}0.001^{*} \\
(0.000)\end{array}$ & $\begin{array}{l}0.001^{*} \\
(0.000)\end{array}$ & $\begin{array}{l}0.001^{* *} \\
(0.000)\end{array}$ & $\begin{array}{c}0.001^{* *} \\
(0.000)\end{array}$ \\
\hline Beds & $\begin{array}{c}-0.121^{*} \\
(0.059)\end{array}$ & $\begin{array}{c}-0.128^{*} \\
(0.061)\end{array}$ & $\begin{array}{c}-0.123^{*} \\
(0.059)\end{array}$ & $\begin{array}{c}-0.124^{*} \\
(0.060)\end{array}$ & $\begin{array}{c}0.021 \\
(0.013)\end{array}$ & $\begin{array}{c}0.021 \\
(0.013)\end{array}$ & $\begin{array}{l}0.022^{+} \\
(0.013)\end{array}$ & $\begin{array}{l}0.022^{+} \\
(0.013)\end{array}$ \\
\hline SARS deaths & $\begin{array}{l}0.000^{*} \\
(0.000)\end{array}$ & $\begin{array}{l}0.000^{*} \\
(0.000)\end{array}$ & $\begin{array}{l}0.000^{* *} \\
(0.000)\end{array}$ & $\begin{array}{l}0.000^{* *} \\
(0.000)\end{array}$ & $\begin{array}{c}-0.000^{* * *} \\
(0.000)\end{array}$ & $\begin{array}{c}-0.000^{* * *} \\
(0.000)\end{array}$ & $\begin{array}{c}-0.000^{* * *} \\
(0.000)\end{array}$ & $\begin{array}{c}-0.000^{* * *} \\
(0.000)\end{array}$ \\
\hline Daily deaths & $\begin{array}{c}0.004 \\
(0.006)\end{array}$ & $\begin{array}{c}0.005 \\
(0.006)\end{array}$ & $\begin{array}{c}0.005 \\
(0.005)\end{array}$ & $\begin{array}{c}0.005 \\
(0.005)\end{array}$ & $\begin{array}{l}-0.004 \\
(0.004)\end{array}$ & $\begin{array}{l}-0.004 \\
(0.004)\end{array}$ & $\begin{array}{l}-0.004 \\
(0.004)\end{array}$ & $\begin{array}{l}-0.004 \\
(0.004)\end{array}$ \\
\hline polity $2 \_2018$ & $\begin{array}{l}0.046^{+} \\
(0.026)\end{array}$ & & & & $\begin{array}{l}-0.012^{*} \\
(0.005)\end{array}$ & & & \\
\hline xconst_2018 & & $\begin{array}{l}0.184^{*} \\
(0.082)\end{array}$ & & & & $\begin{array}{c}-0.044^{* *} \\
(0.017)\end{array}$ & & \\
\hline vdem_polyarchy_2019 & & & $\begin{array}{c}0.641 \\
(0.615)\end{array}$ & & & & $\begin{array}{l}-0.161 \\
(0.129)\end{array}$ & \\
\hline vdem_libdem_2019 & & & & $\begin{array}{c}0.691 \\
(0.617)\end{array}$ & & & & $\begin{array}{l}-0.158 \\
(0.128)\end{array}$ \\
\hline Constant & $\begin{array}{c}-16.103^{* * *} \\
(1.411) \\
\end{array}$ & $\begin{array}{c}-17.094^{* * *} \\
(1.572) \\
\end{array}$ & $\begin{array}{c}-16.004^{* * *} \\
(1.385) \\
\end{array}$ & $\begin{array}{c}-15.954^{* * *} \\
(1.363)\end{array}$ & $\begin{array}{c}4.288^{* * *} \\
(0.217) \\
\end{array}$ & $\begin{array}{c}4.478^{* * *} \\
(0.237) \\
\end{array}$ & $\begin{array}{c}4.294^{* * *} \\
(0.223) \\
\end{array}$ & $\begin{array}{c}4.273^{* * *} \\
(0.218) \\
\end{array}$ \\
\hline $\ln \_p$ & $\begin{array}{c}1.325^{* * *} \\
(0.062)\end{array}$ & $\begin{array}{c}1.337^{* * *} \\
(0.063)\end{array}$ & $\begin{array}{c}1.319^{* * *} \\
(0.059)\end{array}$ & $\begin{array}{c}1.320^{* * *} \\
(0.059)\end{array}$ & & & & \\
\hline lnsigma & & & & & $\begin{array}{c}-1.227^{* * *} \\
(0.080)\end{array}$ & $\begin{array}{c}-1.241^{* * *} \\
(0.081)\end{array}$ & $\begin{array}{c}-1.196^{* * *} \\
(0.076)\end{array}$ & $\begin{array}{c}-1.196^{* * *} \\
(0.076)\end{array}$ \\
\hline$N$ & 13879 & 13758 & 14463 & 14463 & 13879 & 13758 & 14463 & 14463 \\
\hline 11 & -75.162 & -72.850 & -79.320 & -79.212 & -59.119 & -57.107 & -64.406 & -64.427 \\
\hline aic & 168.324 & 163.700 & 176.640 & 176.424 & 136.237 & 132.214 & 146.812 & 146.853 \\
\hline
\end{tabular}

Robust standard errors in parentheses

${ }^{+} p<0.10,{ }^{*} p<0.05,{ }^{* *} p<0.01,{ }^{* * *} p<0.001$ 
Table A.7 Alternative Measures of Democracy on Lockdowns (interaction with deaths)

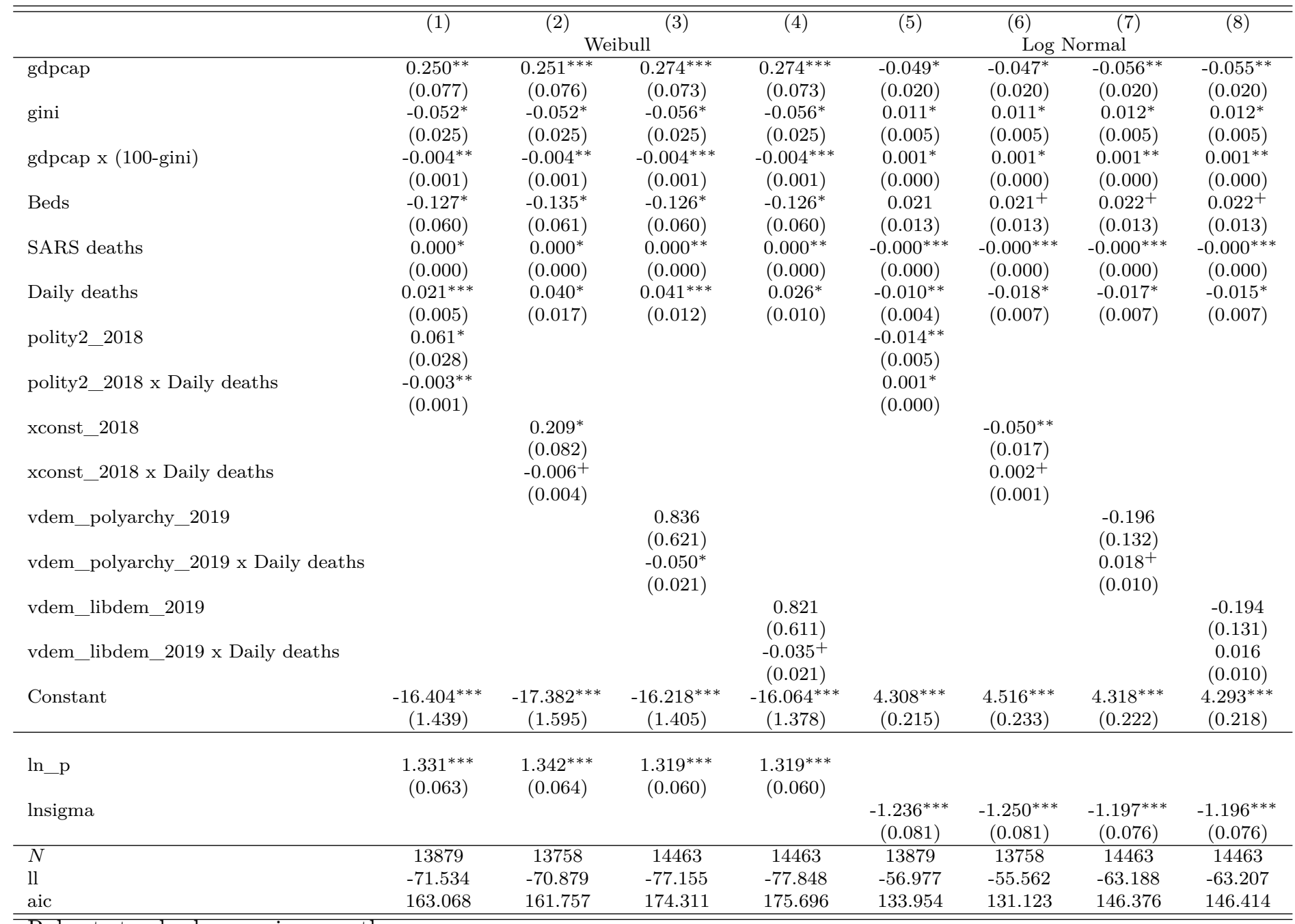

Robust standard errors in parentheses

${ }^{+} p<0.10,{ }^{*} p<0.05,{ }^{* *} p<0.01,{ }^{* * *} p<0.001$ 
Table A.8 Alternative Measures of Democracy on Work Closings

\begin{tabular}{|c|c|c|c|c|c|c|c|c|}
\hline & $\overline{(1)}$ & $\overline{(2)}$ & $(3)$ & $(4)$ & $(5)$ & $(6)$ & $\overline{(7)}$ & $\overline{(8)}$ \\
\hline & \multicolumn{4}{|c|}{ Weibull } & \multicolumn{4}{|c|}{ Log Normal } \\
\hline gdpcap & $\begin{array}{l}0.208^{+} \\
(0.112)\end{array}$ & $\begin{array}{l}0.206^{*} \\
(0.105)\end{array}$ & $\begin{array}{l}0.203^{+} \\
(0.110)\end{array}$ & $\begin{array}{l}0.204^{+} \\
(0.111)\end{array}$ & $\begin{array}{c}-0.066^{*} \\
(0.033)\end{array}$ & $\begin{array}{c}-0.057^{+} \\
(0.034)\end{array}$ & $\begin{array}{r}-0.059^{+} \\
(0.033)\end{array}$ & $\begin{array}{r}-0.059^{+} \\
(0.033)\end{array}$ \\
\hline gini & $\begin{array}{l}-0.027 \\
(0.035)\end{array}$ & $\begin{array}{l}-0.024 \\
(0.034)\end{array}$ & $\begin{array}{l}-0.032 \\
(0.037)\end{array}$ & $\begin{array}{l}-0.030 \\
(0.036)\end{array}$ & $\begin{array}{c}0.007 \\
(0.009)\end{array}$ & $\begin{array}{c}0.005 \\
(0.009)\end{array}$ & $\begin{array}{c}0.008 \\
(0.009)\end{array}$ & $\begin{array}{c}0.008 \\
(0.009)\end{array}$ \\
\hline gdpcap x (100-gini) & $\begin{array}{r}-0.003^{+} \\
(0.002)\end{array}$ & $\begin{array}{r}-0.003^{+} \\
(0.002)\end{array}$ & $\begin{array}{c}-0.003^{+} \\
(0.002)\end{array}$ & $\begin{array}{c}-0.003^{+} \\
(0.002)\end{array}$ & $\begin{array}{l}0.001^{+} \\
(0.001)\end{array}$ & $\begin{array}{c}0.001 \\
(0.001)\end{array}$ & $\begin{array}{l}0.001^{+} \\
(0.001)\end{array}$ & $\begin{array}{l}0.001^{+} \\
(0.001)\end{array}$ \\
\hline Beds & $\begin{array}{c}-0.215^{*} \\
(0.101)\end{array}$ & $\begin{array}{c}-0.221^{*} \\
(0.103)\end{array}$ & $\begin{array}{c}-0.223^{*} \\
(0.104)\end{array}$ & $\begin{array}{c}-0.223^{*} \\
(0.105)\end{array}$ & $\begin{array}{l}0.062^{*} \\
(0.026)\end{array}$ & $\begin{array}{l}0.060^{*} \\
(0.026)\end{array}$ & $\begin{array}{l}0.067^{*} \\
(0.027)\end{array}$ & $\begin{array}{l}0.066^{*} \\
(0.027)\end{array}$ \\
\hline SARS deaths & $\begin{array}{l}-0.000 \\
(0.000)\end{array}$ & $\begin{array}{l}-0.000 \\
(0.000)\end{array}$ & $\begin{array}{l}-0.000 \\
(0.000)\end{array}$ & $\begin{array}{l}-0.000 \\
(0.000)\end{array}$ & $\begin{array}{c}0.000 \\
(0.000)\end{array}$ & $\begin{array}{c}0.000 \\
(0.000)\end{array}$ & $\begin{array}{c}0.000 \\
(0.000)\end{array}$ & $\begin{array}{c}0.000 \\
(0.000)\end{array}$ \\
\hline Daily deaths & $\begin{array}{c}0.004^{* * *} \\
(0.001)\end{array}$ & $\begin{array}{c}0.004^{* * *} \\
(0.001)\end{array}$ & $\begin{array}{c}0.004^{* * *} \\
(0.001)\end{array}$ & $\begin{array}{c}0.004^{* * *} \\
(0.001)\end{array}$ & $\begin{array}{l}-0.002 \\
(0.002)\end{array}$ & $\begin{array}{l}-0.002 \\
(0.002)\end{array}$ & $\begin{array}{l}-0.002 \\
(0.002)\end{array}$ & $\begin{array}{l}-0.002 \\
(0.002)\end{array}$ \\
\hline polity2_2018 & $\begin{array}{l}0.109^{*} \\
(0.048)\end{array}$ & & & & $\begin{array}{c}-0.033^{* *} \\
(0.011)\end{array}$ & & & \\
\hline xconst_2018 & & $\begin{array}{c}0.343^{* *} \\
(0.133)\end{array}$ & & & & $\begin{array}{c}-0.102^{* *} \\
(0.033)\end{array}$ & & \\
\hline vdem_polyarchy_2019 & & & $\begin{array}{l}2.333^{*} \\
(0.947)\end{array}$ & & & & $\begin{array}{c}-0.777^{* *} \\
(0.253)\end{array}$ & \\
\hline vdem_libdem_2019 & & & & $\begin{array}{l}2.138^{*} \\
(0.842)\end{array}$ & & & & $\begin{array}{c}-0.756^{* *} \\
(0.241)\end{array}$ \\
\hline Constant & $\begin{array}{c}-14.987^{* * *} \\
(1.628) \\
\end{array}$ & $\begin{array}{c}-16.483^{* * *} \\
(1.749) \\
\end{array}$ & $\begin{array}{c}-15.277^{* * *} \\
(1.697) \\
\end{array}$ & $\begin{array}{c}-14.936^{* * *} \\
(1.615) \\
\end{array}$ & $\begin{array}{c}4.860^{* * *} \\
(0.388) \\
\end{array}$ & $\begin{array}{c}5.324^{* * *} \\
(0.442) \\
\end{array}$ & $\begin{array}{c}5.023^{* * *} \\
(0.402) \\
\end{array}$ & $\begin{array}{c}4.916^{* * *} \\
(0.387) \\
\end{array}$ \\
\hline $\ln \_p$ & $\begin{array}{c}1.115^{* * *} \\
(0.052)\end{array}$ & $\begin{array}{c}1.123^{* * *} \\
(0.054)\end{array}$ & $\begin{array}{c}1.109^{* * *} \\
(0.050)\end{array}$ & $\begin{array}{c}1.108^{* * *} \\
(0.049)\end{array}$ & & & & \\
\hline lnsigma & & & & & $\begin{array}{c}-0.781^{* * *} \\
(0.088)\end{array}$ & $\begin{array}{c}-0.787^{* * *} \\
(0.088)\end{array}$ & $\begin{array}{c}-0.768^{* * *} \\
(0.086)\end{array}$ & $\begin{array}{c}-0.769^{* * *} \\
(0.085)\end{array}$ \\
\hline$N$ & 15503 & 15382 & 16108 & 16108 & 15503 & 15382 & 16108 & 16108 \\
\hline 11 & -70.515 & -69.896 & -72.663 & -72.870 & -65.836 & -65.491 & -67.904 & -68.004 \\
\hline aic & 159.031 & 157.792 & 163.326 & 163.741 & 149.671 & 148.983 & 153.808 & 154.008 \\
\hline
\end{tabular}

Robust standard errors in parentheses

${ }^{+} p<0.10,{ }^{*} p<0.05,{ }^{* *} p<0.01,{ }^{* * *} p<0.001$ 
Table A.9 Alternative Measures of Democracy on Work Closings (interaction with deaths)

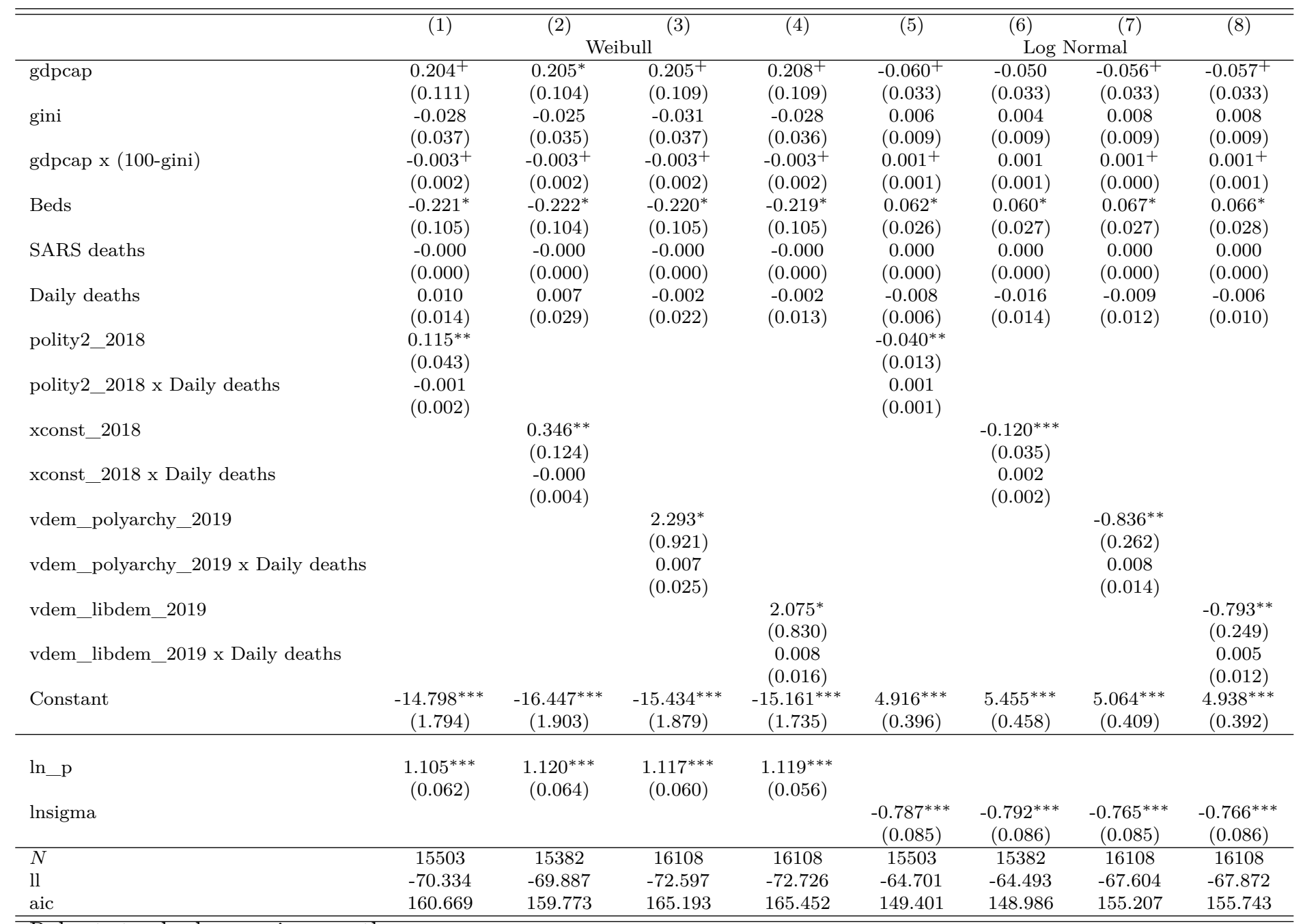

\footnotetext{
Robust standard errors in parentheses

${ }^{+} p<0.10,{ }^{*} p<0.05,{ }^{* *} p<0.01,{ }^{* * *} p<0.001$
} 


\section{Codebook}

Observations are organized as country-day.

countryn

Country name.

country

Country numeric code, ranging from 1 to 192. Total number of countries is 191 (numbering goes from $128=$ Nigeria to $130=$ Norway).

days

Days counter. Days $=1$ for January 1, 2020 .

id

Country-day unique identifies. ID $=\left(\right.$ COUNTRY $\left.^{*} 1000\right)+$ DAYS.

\section{lockdown}

Variable identifying the occurrence of a lockdown. Coded as:

1 If a government issued an order for people not to move out of their places of residence other than for specified reasons and this order covers an entire country. The first 1 is coded for the day after the announcement or the day for which it is supposed to apply, if different. Since we are not tracking if and when orders were lifted, it is coded 1 for the rest of the period.

0 If no lockdown order was issued at the local and national level, even if the government called for a voluntary restraint of movements. Night curfews, restrictions limited to people over some age, appeals to voluntarily restrict movement, bans on vehicle circulation, cordons of particular localities, or closings of some internal borders are not considered as lockdown.

2 If lockdowns were ordered at some subnational levels but not at the national level. Note that in some federal systems the national government does not have the power to issue lockdown orders.

The language identifying restrictions on movement varies across sources: often such restrictions are identified as "quarantine," sometimes as "lockdown," sometimes as "confinement," "isolation," or "shutdown." Sometimes these terms reflect differences among measures taken by governments but often different words are used to describe the same set of restrictions. This is the main source of discrepancy between our and the Oxford data, which in addition to glaring errors lump together as "domestic travel restrictions" (variable s6) any reference to such restrictions.

We define lockdown narrowly as compulsory limitations on leaving places of res- 
idence, applied indiscriminately to everyone except specified categories of people (such as "essential workers") or specified purposes (such as shopping or recreation). Thus, we do not consider lockdown cases in which the government urges, asks or invites people to stay home. Closings of public services and some business (cafés, restaurants, non-essential shops, brothels, etc.) are not considered lockdown. Lockdown applies to persons. We distinguish curfews from lockdown: restrictions lasting less than 24 hours are curfews but not lockdowns; "curfews that last longer than 24 hours are lockdowns. In some countries lockdowns occurred for multiple and short periods of time (e.g., lockdowns from Friday through Monday, but repeated for multiple weekends). We code the first day of the first period as lockdown $>0$. Note importantly that it is possible for a lockdown to be in place and for people being able to work (lockdown=1, work $=0)$. This is true when the exclusions to the ban on movements include travel to and from work. Poland is an example. Lockdown is coded 0 if only specific groups are targeted, e.g., people over 65, children under 12. We do not code whether the order was enforced.

\section{fed_lock}

Modified indicator of lockdown.

1 if lockdown $=1$ OR $($ lockdown $=1$ AND federal $=4)$

2 if lockdown $=2$.

0 if lockdown $=0$.

\section{meet}

This variable indicates bans on public meetings. Coded as:

\#\#\# If there is a ban and the size of the largest gathering is specified, this the number.

1 If there is a ban but the largest size is not available or if lockdown=1.

0 If there is no ban.

In addition, we add a 01 to the code if religious meetings are explicitly included and 02 if they are explicitly excluded. All bans that only mention religious observances are coded as 1 . Subnational bans are coded as 1 .

meet_dummy

Dummy variable coded 1 if meet $>0$, 0 otherwise.

\section{work}

This variable indicates closings of non-essential offices, production, and construction sites. Coded as:

0 If open.

1 If closed. Applies only to offices, production, and construction sites. Closing of public spaces such as cafes, restaurants, department stores offering non-essential goods, barber shops, brothels (as in Bangladesh), etc. is not included.

2 If restrictions apply only in parts of the country, or are associated with lockdown 


$$
=2 \text {. }
$$

\section{schools}

School closures, coded 1 national, 2 if localized, 3 if open. 3 is only given to the cases that in the original file were indicated as open. Source: UNESCO.

\section{newschools}

Identical to schools but 3 is coded as 0 . Here, 0 means the schools were listed as open in the UNESCO file or the cases were missing in the UNESCO file.

\section{fed_school}

Modified indicator of newschools.

1 if newschools $=1 \mathrm{OR}$ (newschools $=2$ AND federal $=4$ )

2 if newschools $=2$.

0 if newschools $=0$.

\section{severity}

Ordinal variable coded to indicate the degree of severity of the measures taken by the government.

0 No measures were taken (newschools $=0 \&$ meet $=0 \&$ lock $=0 \&$ work $=0$ ).

1 School closures only (newschools $=1$ \& meet $=0$ \& lock $=0$ \& work $=0$ ).

2 School closures and meetings banned (newschools $=1$ \& meet $=1$ \& lock=0 \& work $=0)$.

3 School closures, meetings banned, lockdown ordered (newschools $=1$ \& meet $=1$ \& lock $=1 \&$ work $=0$ ).

4 School closures, meeting banned, lockdown ordered, work suspended (newschools=1 $\&$ meet $=1 \&$ lock $=1 \&$ work $=1$ ).

-8 Local school closures and local lockdown (newschools=2 \& lockdown=2).

-9 National measures deviate from the pattern.

\section{fed_severity}

Identical to severity but using fed_lock in place of lockdown and fed_school instead of newschools.

\section{cases}

Number of known cases of COVID-19. Source: ECDPC.

\section{deaths}

Cumulative deaths from COVID-19. Source: ECDPC.

\section{deathrate}

Deaths from COVID-19 per million: (deaths/pop_2018)*1,000,000. 


\section{cumdeathrate}

Cumulative deaths from COVID-19 per million: (cumdeaths/pop_2018)*1,000,000.

first_death_day

The day the first death was recorded. Country-invariant.

since_first_death

Counter indicating the number of days in relation to the day the first death was recorded. Positive (negative) numbers refer to days after (before) the first day.

\section{Tschool}

Variable coded 1 for the first day schools were closed. If school were never closed during the entire period, Tschool $=1$ when days $=121$.

\section{Tmeet}

Variable coded 1 for the first day meetings were banned. If meetings were never banned during the entire period, Tmeet $=1$ when days $=121$.

\section{Tlock}

Variable coded 1 for the first day of lockdown. If there was no lockdown during the entire period, Tlock $=1$ when days $=121$.

\section{Twork}

Variable coded 1 for the first day work was suspended. If work was never suspended during the entire period, Twork $=1$ when days $=121$.

\section{old_regime}

0 Autocracy.

1 Democracy.

2 Unknown.

3 No regime.

The regime classification conceptually and operationally follows the rules in Alvarez et al (1996), Przeworski et al (2000) and (Cheibub, Gandhi and Vreland (2010), with small changes that do not violate their thrust. Democracy is defined as the regime in which rulers are selected through competitive elections. This situation occurs when: (1) The chief executive is popularly elected; (2) The national legislature is popularly elected; (3) There are at least two alternatives for voters to choose from in elections; (4) There has been an alternation in power under the rules that brought the incumbent to office. Thus, an alternation takes place when the incumbent occupying the chief executive office is replaced through elections that were organized under the same rules as the ones that brought him to office. Autocracies are regimes that violate at least one of those rules. 
As extensively discussed in previous publications, in some cases the chief executive officer and legislators were chosen through multiparty elections, but these officers never lost an election. Incumbent victory in these cases can be the result of popularity or manipulation. If the former, then the regime should be considered democratic; if the latter, then it is likely that elections only happen because the incumbent is certain that he will win. Since we cannot observe the incumbent's intentions and we do not know what will happen in the future, we code these cases separately. They do not represent an intermediate regime category; they are either a democracy or an autocracy the nature of which is not determinable with the information available.

The original dichotomous regime classification was motivated by whether democracies would lead to higher levels of economic growth. In that case, the goal was to generate a "clean" sample of democratic regimes. For this reason, when implementing the classification rules, the choice was to avoid type II errors, that is, to avoid accepting as democracies cases that were in fact dictatorships. Today these cases are of interest themselves. They can be interpreted as a measure of the "soft" authoritarianism that has become the hallmark of many political regimes in the 21st century. Classified as "unknown" are most of the cases that are at the center of the literature on democratic erosion and the like. This way of thinking about the "type II regimes" provides a rule-based coding of cases that the literature has found extremely difficult to identify systematically.

regime

0 Autocracy.

1 Democracy.

Dichotomous regime classification. This. variable was generated by recoding the "unknown" regimes in old_regime. Recall that these are the regimes that could be a democracy since they have elections in which voters are offered at least two alternatives to choose from; but they have never experienced an alternation in power. Thus, in these cases, the incumbent (the president, the party, or the coalition) held but never lost multiparty elections. Further investigation showed that cases like these come into existence in three ways: (a) The current incumbent won elections and their victory indicated an alternation in power; (b) The incumbent came to power at independence and has remained in power since then; (c) The incumbent came to power as a result of some sort of violent conflict (coups, civil wars, street protests) and remained in power while holding multiparty elections. Given this, we adopted the following procedure for coding these cases as democracies or dictatorships:

1. Incumbents who came to power as the result of "alternation elections" were coded as democracies.

2. Incumbents who came to power as the result of conflicts and never lost elections were coded as autocracies. 
3. Incumbents who came to power at independence and never lost were coded as autocracies if, on average in the life of the regime, they won more than $60 \%$ of the seats in legislative elections and of the votes in presidential elections OR if they won more than $75 \%$ of the seats in legislative elections. If these two conditions were not met, they were coded as democracies (only Montenegro and Samoa all into this category). Note that this decision is strengthened if we also consider the threshold for constitutional amendment in each of these cases. Excluding Montenegro and Samoa, there are 15 countries where the incumbent has been in office since idependence. In 11 of them, the average share of legislative seats held by the incumbent was well above the threshold for constitutional amendment. In 3 of the remaining four - Mozambique, Russia, and Zimbabwe - the average share of seats held by the incumbent was not far from the $2 / 3$ threshold required by the constitution $(62.7 \%, 62.2 \%$, and $65.6 \%$, respectively). Finally, in Azerbaijan, the average seats held by the incumbent was only $54 \%$ while the threshold for constitutional amendment was $3 / 4$; but the president won on average $85 \%$ of the vote over 7 elections and the second largest group in the legislature during the entire period were "independents."

vdem_polyarchy_2019

Varieties of Democracy polyarchy index in 2019. Source: V-DEM 2018.

vdem_libdem_2019

Varieties of Democracy liberal democracy index in 2019. Source: V-DEM 2018.

polity 2_2018

Combined POLITY score (modified). Source: Polity Project.

xconst_2018

Executive Constraints. Source: Polity Project.

pop_2018

Country's population in 2018. Source: ECDPC [World Bank].

female_leader

Dummy variable coded 1 if the country's chief executive was female.

no_ufs

Federalism 1: Dummy variable coded 1 if the country is federal. Source: QOD2020 [Pipa Norris, Democracy Time-series Data Release 3.0, January 2009]. 
pt_federal

Federalism 2: Dummy variable coded 1 if the has a federal political structure. Source: QOD2020 [Persson \& Tabellini, The Economic Effects of Constitutions, 2003].

h_f

Federalism 3: Dummy variable coded 1 if there are independent sub-federal units that impose substantive constraints on national fiscal policy. Source: QOD2020 [Henisz, Political Constraint Index (POLCON) Dataset].

iaep_ufs

Federalism 4: Structure of the government (relationship between central and regional governments, those that are immediately below the central government; focus is exclusively on states or provincial levels of government; municipalities are not coded). Source: QOD2020

1 Unitary system.

2 Confederation.

3 Federal System.

federal

Indicator for federal countries, based on the sum of the four previous indicators of federalism. Federal countries are those where federal $=4$.

deaths_per1000

Number of annual deaths per 1000 inhabitants, most recent observation. Source: World Bank.

beds

Hospital beds per 1000 inhabitants, most recent observation. Source: World Bank.

nurse_per1000

Number of nurses per 1000 inhabitants, most recent observation. Source: World Bank.

physician_per1000

Number of physicians per 1000 inhabitants, most recent observation. Source: World Bank.

mers_deaths

Number of deaths attributed to MERS. Source: Wikipedia:

https://en.wikipedia.org/wiki/Middle_East_respiratory_syndrome 
sars_deaths

Number of deaths attributed to SARS. Source: Wikipedia

https://en.wikipedia.org/wiki/2002\%E2\%80\%932004_SARS_outbreak

\section{urbanpop}

Share of urban population, most recent observation. Source: World Bank.

gini__wb

GINI coefficient, most recent observation. Source: World Bank.

gdpc_mpd

GDP per capita in 2016. Source: Maddison Project Database (2018).

africa

Dummy variable coded 1 for all countries located in Africa, 0 otherwise.

subsahara

Dummy variable coded 1 for all countries located in Sub-Sahara Africa, 0 otherwise.

island

Dummy variable coded 1 for all island countries, 0 otherwise.

\section{smallisland}

Dummy variable coded 1 for all island countries with population under 1 million people.

\section{OECD1990}

Dummy variable coded 1 for all countries that belonged to the OECD in 1990, excluding Turkey.

\section{SOURCES}

\section{ECDPC}

European Center for Disease Prevention and Control.

https://www.ecdc .europa.eu/en/publications-data/download-todays-data-geographic

-distribution-covid-19-cases-worldwide

\section{MEASURES}

Data were originally collected, relying on articles in Wikipedia, footnotes in these articles, announcements by governments, newspaper coverage, and whatever other sources we could find on the web. We also consulted the International Monetary Fund Policy Responses to COVID-19 tracker; the International Center for Not-for-profit 
Law, Coronavirus and Civic Space, COVID-19 Civid Freedom Tracker; Garda World News Alert; WorldAware, COVID-19 and SARS-CoV-2 Intelligence Alerts; ACAPS.

https://www.imf.org/en/Topics/imf-and-covid19/Policy-Responses-to-COVID-19\#S

https://www.icnl.org/coronavirus-response

https://www . garda.com/crisis24/news-alerts

https://www.worldaware.com/resources/intelligence-alerts/covid-19-and-sars-cov-2-।

intelligence-alerts-april-2020

\section{OXFORD-2000}

Hale, Thomas, Anna Petherick, Toby Phillips, Samuel Webster. "Variation in Government Responses to COVID-19" Version 4.0. Blavatnik School of Government Working Paper. April 7, 2020.

www.bsg.ox.ac.uk/covidtracker

\section{Polity Project}

Marshall, Monty G. and Ted Robert Gurr. 2020. POLITY 5: Dataset User's Manual. Center for Systemic Peace.

wWw.systemicpeace.org

\section{REGIME}

Cheibub, Gandhi and Vreeland (2010) and multiple country-specific sources.

\section{QOG2020}

Teorell, Jan, Stefan Dahlberg, Sören Homberg, Bo Rothstein, Natalia Alvarado Pachon and Soa Axelsson. 2020. The Quality of Government Standard Dataset, version Jan20. University of Gothenburg: The Quality of Government Institute.

http://www.qog.pol.gu.sedoi:10.18157/qogstdjan20

\section{UNESCO}

Covid-19 Impact on Education.

https://en.unesco.org/covid19/educationresponse.

\section{VDEM 2018}

Coppedge, Michael et al. 2018. "V-Dem Codebook, v.8." Varieties of Democracy (VDem) Project.

https://doi.org/10.23696/vdemcy18

\section{WORLD BANK}

World Development Indicators.

(https://databank. worldbank.org/source/world-development-indicators. 